\title{
Sedimentary provenance of the Plio-Pleistocene Nicobar Fan: Complex sourcing revealed through Raman spectroscopy heavy mineral analysis
}

\author{
Max Webb ${ }^{\text {a, * }}$, Amy Gough ${ }^{\text {a }}$, Paola Vannucchi ${ }^{b}$, Nils K. Lünsdorf ${ }^{c}$, Joseph McNeil $^{\mathrm{d}}$ \\ ${ }^{a}$ SE Asia Research Group, Department of Earth Sciences, Royal Holloway University of London, Egham, Surrey, UK \\ ${ }^{\mathrm{b}}$ Earth Sciences Department, Università degli Studi di Firenze, Florence, Italy \\ ${ }^{c}$ Department of Sedimentology and Environmental Geology, Centre of Geosciences, Georg-August University, Göttingen, Germany \\ d School of Physical Sciences, The Open University, Milton Keynes, UK
}

\section{A R T I C L E I N F O}

\section{Keywords:}

Sedimentary provenance

Raman spectroscopy

Bengal-Nicobar fan

Indian Ocean tectonics

IODP Expedition 362

Sunda subduction zone

\begin{abstract}
A B S T R A C T
The Nicobar Fan lies within the north-eastern Indian Ocean between the Ninety-East Ridge and Sunda Arc. The fan forms part of the Bengal-Nicobar Fan System and is among the oldest and largest submarine fans on Earth. Previous U-Pb zircon studies of the Nicobar and Bengal fans indicate the Himalaya as the dominate sediment source, making these fans a major Cenozoic sink for uplifted Himalayan sediment. However, the northwards moving Indian Plate, coupled with mid-Pleistocene collision of the Ninety-East Ridge with the Sunda Arc, has shutdown many sediment pathways linking the Himalaya and Nicobar Fan. Here we use big data Raman spectroscopy heavy mineral analysis along with $\mathrm{U}-\mathrm{Pb}$ zircon data to better define sediment source regions for the Nicobar Fan during the Plio-Pleistocene following the shutdown of sediment delivery. The detrital zircon spectra for the Plio-Pleistocene Nicobar Fan from this study are consistent with previous work indicating that the original sources of these zircons can be found within both the Greater and Tethyan Himalaya, the Gangdese Arc, and the Indo-Myanmar Ranges. However, the heavy mineral data indicate that a large proportion of sediment has been derived from a more complex array of sources. This is coupled with an abundance of low- and moderate-stability minerals (e.g., amphibole, apatite, clinopyroxene), which are unlikely to have been transported large distances. Suggesting that proximal sources have delivered the majority of lower-stability heavy minerals into the PlioPleistocene Nicobar Fan. We show that from the Pleistocene onwards direct sediment delivery into the Nicobar Fan from the Himalaya was largely shutdown, with sediment instead shedding off the uplifting IndoMyanmar Ranges, the Andaman-Nicobar Accretionary Ridge, and the westwards propagating Ayeyarwady River. This study shows that extensive uplift along the northern Sunda Arc is recorded in the Nicobar Fan alongside the previously reported Himalayan record.
\end{abstract}

\section{Introduction}

This study analyses core samples from Plio-Pleistocene sediments of the Nicobar Fan, drilled during International Ocean Discovery Program (IODP) Expedition 362, to better understand the source of these sediments and the role late Cenozoic tectonics has played in sediment routing into the fan. The provenance of sands into the neighbouring and larger Bengal Fan has been extensively studied using combined light mineral analysis, heavy mineral analysis, detrital grain geochronology, and geochemistry (Galy et al., 2010; France-Lanord et al., 2016; Blum et al., 2018; Najman et al., 2019; Huyghe et al., 2020). However, detailed studies on the provenance of the Nicobar Fan remains limited to light mineral analysis, geochemical analysis, and $\mathrm{U}-\mathrm{Pb}$ zircon geochronology of dominantly Neogene deposits (Ingersoll and Suczek, 1979; McNeill et al., 2017; Chen et al., 2020; Pickering et al., 2020b), with detailed heavy mineral analysis currently lacking. Previous studies indicate that the Miocene Nicobar Fan sampled during IODP 362 consists of similar mica-dominated quartzo-feldspathic sands as those found in the Bengal Fan (France-Lanord et al., 2016; McNeill et al., 2017; Pickering et al., 2020b), heavy mineral assemblages were initially reported as being abundantly metamorphic-derived (e.g., kyanite and sillimanite; McNeill et al., 2017) with more recent studies instead reporting abundant amphibole-epidote-garnet assemblages (Pickering et al., 2020b). The detrital zircon spectra for Miocene deposits indicate

\footnotetext{
* Corresponding author.

E-mail address: max.cm.webb@gmail.com (M. Webb).
} 
derivation from both the Greater and Tethyan Himalayan sequences (GHS and THS), the Transhimalayan and Gangdese arcs, and the Palaeogene Indo-Myanmar Ranges (IMR; McNeill et al., 2017; Pickering et al., 2020b).

However, the recent tectonic evolution of the region surrounding the Nicobar Fan presents problems for a directly Himalayan-derived source of Plio-Pleistocene sands into the fan. Collision of the Ninety-East Ridge with the Sunda Arc in the mid-Pleistocene (Curray and Moore, 1974; Moore et al., 1982; Subrahmanyam et al., 2008; Sun et al., 2018) means that sediment input from the north would have been largely shut-off into the Nicobar Fan. This, coupled with the Plio-Pleistocene western propagation of the IMR (Najman et al., 2020), exhumation of the Eastern Himalayan Syntaxis (Booth et al., 2009; Najman et al., 2016), final uplift of the Andaman-Nicobar Accretionary Ridge (ANAR; Allen et al., 2008a), and increased volcanism along the Sunda Arc (De Smet and Barber, 2005; Ray et al., 2013), suggests that the provenance of Plio-Pleistocene sediments in the Nicobar Fan may be far more complex than previously thought.

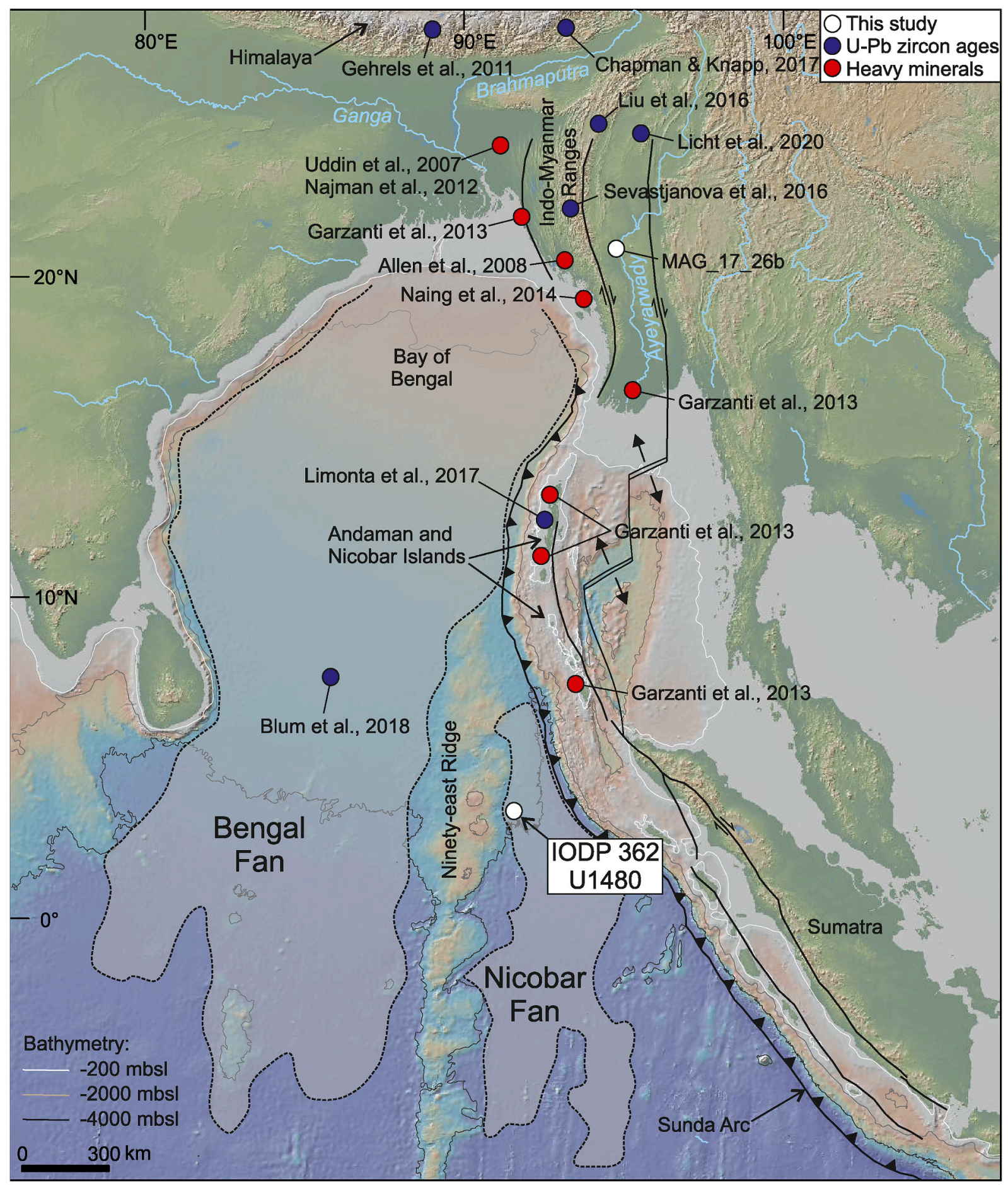

Fig. 1. Map showing the present-day location and extent of the Nicobar and Bengal fans and the location of IODP 362 drill site U1480. Also shown are the main river systems and tectonic structures (from Hall, 2012) and the sites of U-Pb zircon and heavy mineral studies that have been used for comparison with our data. Map data is from Ryan et al. (2009) and bathymetric data is from GEBCO (2003). 
Here we present a combined big data heavy mineral and U-Pb detrital zircon study of Plio-Pleistocene deposits of the Nicobar Fan to better understand the provenance of sediments into the fan and its relationship to increased regional uplift and volcanism in the late Cenozoic.

\section{Regional setting and background}

The Nicobar Fan sits within the north-eastern Indian Ocean, flanked by the Ninety-East Ridge to the west and the Sunda Arc and ANAR to the east (Fig. 1). The fan forms part of the larger Bengal-Nicobar Fan System (BNFS), which has been active since the Paleocene and covers an area of $\sim 4,000,000 \mathrm{~km}^{2}$ (Blum et al., 2018; Pickering et al., 2020a), making it among the oldest and largest submarine fans on Earth (Bowles et al., 1978; Schwenk and Spiess, 2009; Curray, 2014; Pickering et al., 2020a). The larger Bengal Fan has been more extensively studied than the Nicobar Fan and is thought to contain a detailed record of the uplift and erosion of the Himalayan mountain belt since the Paleocene (Clift et al., 2008; Najman et al., 2008, 2019; Schwenk and Spie $\beta, 2009$; France-Lanord et al., 2016; Krishna et al., 2016; Blum et al., 2018). These Bengal Fan sediments comprise quartzo-feldspathic sands derived dominantly from the Ganga and Brahmaputra rivers (France-Lanord et al., 2016, Fig. 1).

The Nicobar Fan itself is $\sim 500,000 \mathrm{~km}^{2}$ in size, has been active since the early Miocene ( $\sim 19 \mathrm{Ma})$, and is interpreted to have been deposited as a series of turbidites (Pickering et al., 2020a). Sediment accumulation rates (SARs) were highest from $\sim 9$ to $2 \mathrm{Ma}$ (and in particular from $\sim 2.5$ to $2 \mathrm{Ma}$ ) when $\sim 1500 \mathrm{~m}$ of interbedded sands and muds were deposited (Fig. 2a; McNeill et al., 2017; Pickering et al., 2020a). The SARs in the
Nicobar Fan decreased significantly in the Pleistocene, dropping first at $\sim 2 \mathrm{Ma}$, then again at $\sim 1.7 \mathrm{Ma}$ (Fig. 2b; McNeill et al., 2017; Pickering et al., 2020a), and sedimentation is thought to now be solely pelagic. This sudden decrease in sediment supply is the result of either large-scale avulsion of the entire BNFS (Pickering et al., 2020a) or the mid-Pleistocene onset of collision and subduction of the Ninety-East Ridge beneath the Sunda Arc during the northwards movement of the Indian Plate (Curray and Moore, 1974; Moore et al., 1982; Subrahmanyam et al., 2008; Sun et al., 2018), thereby shutting any sediment pathways between the Bengal and Nicobar fans (Fig. 1). The Indian Plate has been moving northwards since the Late Cretaceous decreasing from $\sim 200 \mathrm{~mm} / \mathrm{yr}$ to its present rate of $\sim 50 \mathrm{~mm} / \mathrm{yr}$ following initial subduction beneath, and now collision with the Eurasian Plate (White and Lister, 2012).

North-easterly subduction of the Indian Plate beneath Sundaland along the Sunda Arc began in the middle Eocene (Hall, 2012) coeval with the deposition of thick successions of sediment from the uplifting and eroding Himalaya into the Bengal Fan (Clift et al., 2008; Najman et al., 2008, 2019; Schwenk and Spieß, 2009; France-Lanord et al., 2016; Krishna et al., 2016; Blum et al., 2018). During this subduction, sediments of the Bengal Fan were accreted to the Sunda subduction zone, forming the Oligocene Andaman Flysch and the ANAR that currently borders the Nicobar Fan (Clift, 2017; Limonta et al., 2017), and the western IMR to the north (United Nations, 1979; Allen et al., 2008b; Maurin and Rangin, 2009; Mitchell et al., 2010; Naing et al., 2014). Collision of the Ninety-East Ridge, increased volcanic activity along the Sunda Arc, and extensive uplift since the Plio-Pleistocene have all played a role in the present-day isolation of the Nicobar Fan and the re-routing of the sediment pathways sourcing it.

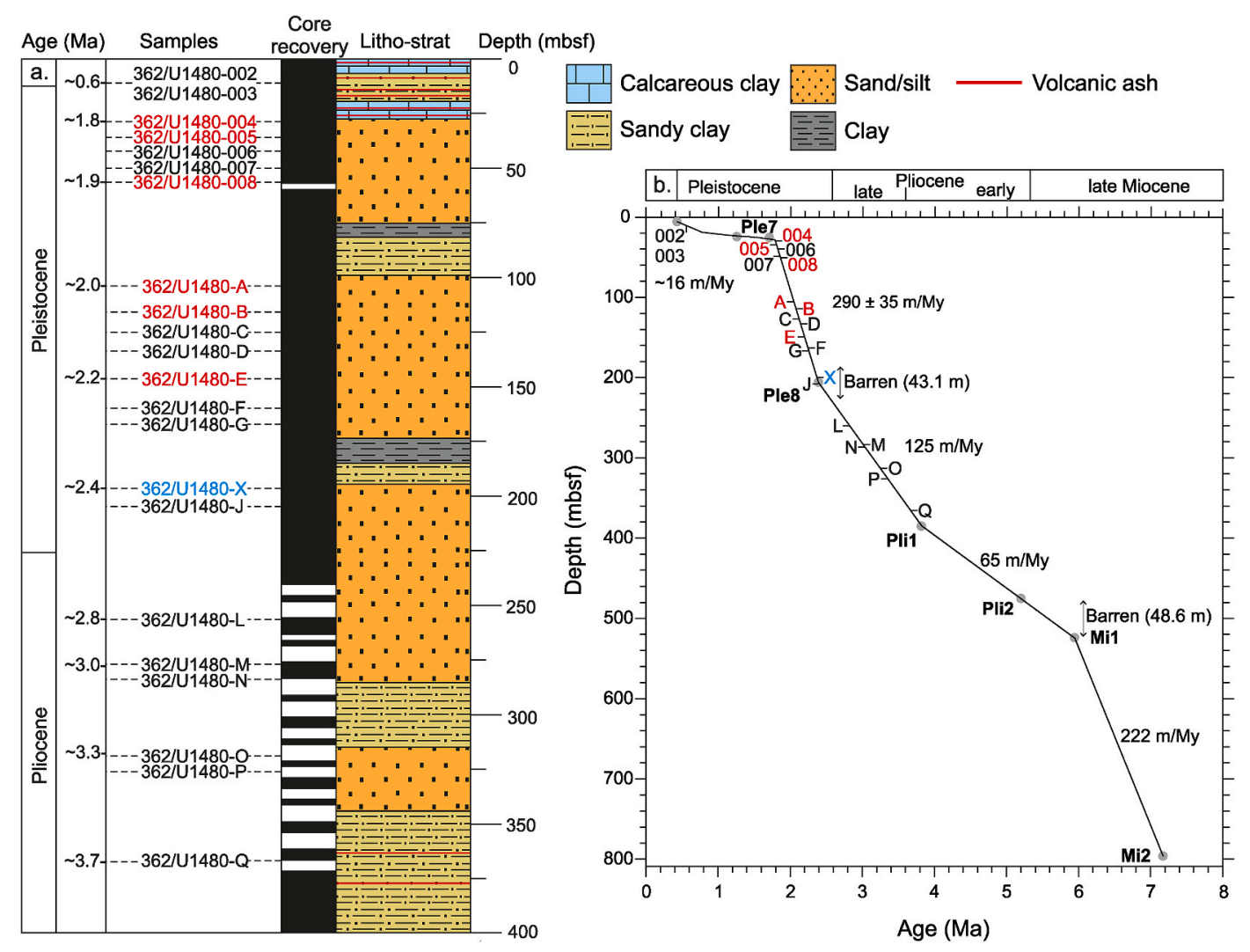

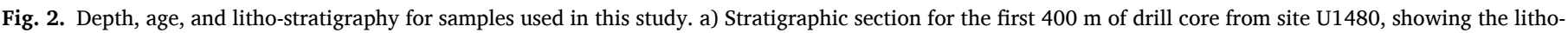

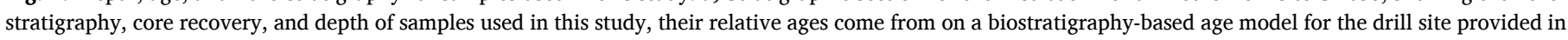

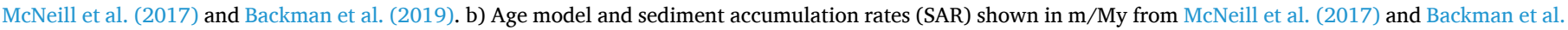

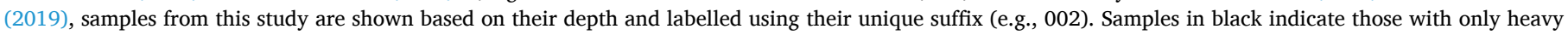

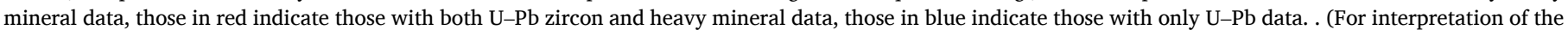
references to colour in this figure legend, the reader is referred to the Web version of this article.) 


\section{Methods}

\subsection{Sample collection}

Core samples used during this study were collected from drill site U1480 during IODP Expedition 362 in 2016. Samples were collected at depths between $\sim 9.3$ and $\sim 367.5 \mathrm{mbsf}$ from holes U1480 E (7-53 mbsf) and U1480 F (105-388 mbsf), these samples have relative ages between $\sim 3.7$ and $\sim 0.6 \mathrm{Ma}$ (Fig. 2) based on a biostratigraphic age model for the drill site (McNeill et al., 2017). More details on the samples used in this study can be found in Supplementary Data File 1 and details on the coring methodology and expedition can be found in McNeill et al. (2017). An additional river sand sample was collected from the middle course of the Ayeyarwady River near the town of Magway, Myanmar (Fig. 1) for heavy mineral analysis and comparison with the IODP core data and other regional heavy mineral studies.

\subsection{Raman heavy mineral analysis}

Automated heavy mineral analysis using Raman Spectroscopy is used to mitigate for human bias in optical heavy mineral counting (Dunkl et al., 2020) and to help to distinguish polymorphs and opaque mineral phases (Shebanove and Lazor, 2003).

For this study, heavy minerals were separated from light minerals using lithium heteropolytungstates (LST) with a density of $289 \pm 0.02 \mathrm{~g} /$ $\mathrm{mL}$ at Royal Holloway, University of London (RHUL). All further analyses were conducted at the Georg-August University, Germany. Heavy mineral separates were mounted in Araldite epoxy resin and polished with corundum-polish to expose the grains. Each mount contains the heavy minerals of 15 samples. These mounts were imaged in both reflected and transmitted light on a Zeiss Axio Imager 2 microscope. Each grain is then individually selected from these images for $\mathrm{X}-\mathrm{Y}$ coordinate setting and measurement with an additional ten points set directly in the resin to establish a baseline of the resin spectroscopy and the correction of miss-placed measurement spots.

A Horiba XploRA Raman was then used with a 532 ųm laser coupled to an Olympus polarising microscope with a lens set at $\times 50$ objective. The Raman is calibrated using silicon prior to use, and then acetaminophen as a standard, measured every 200 grains, further measurement parameters and setup can be found in Lünsdorf et al. (2019). The resultant spectra are run through the RRUFF database (Lafuente et al., 2015) to assign a 'best fit' coefficient, with a result of ' 0 ' being a perfect fit and ' 1 ' no fit to any known heavy mineral spectrum. Results of 0-0.15 are deemed 'good hits' and accepted, 0.15 to 0.30 represent 'medium hits' and are treated with caution, but accepted, and all results over 0.30 are considered 'bad hits' and rejected. Heavy mineral analysis from all samples analysed in this study can be found in Supplementary Data File 2 .

\section{3. $U-P b$ zircon geochronology}

Zircon grains were extracted from core samples using standard density, magnetic susceptibility, and heavy liquid separation techniques at RHUL. The zircons extracted from each sample were mounted in epoxy resin and polished to expose the mid-section of each grain. Cathodoluminescence (CL) imagery was obtained using a Zeiss EVO 15LS scanning electron microscope at the Natural History Museum (NHM) collecting both RGB and greyscale images, these were used to locate internal zircon growth zones to target using laser ablation inductively coupled plasma mass spectrometry (LA-ICP-MS).

$\mathrm{U}-\mathrm{Pb}$ isotopic data were collected using an ESI NWR $193 \mathrm{~nm}$ laser ablation system coupled to an Agilent 7700 quadrupole-based ICP-MS at the London Geochronology Centre (LGC), University College London (UCL). The instrument parameters were kept the same between each session and between each analysis. The LA-ICP-MS parameters are largely the same as those adopted by Jackson et al. (2004) and further details are provided in Supplementary Data File 3.

Plešovice zircon (337.13 \pm 0.37 Ma, Sláma et al., 2008) was used as an external age standard to correct for mass bias and down-hole fractionation. Three Plešovice zircons were measured at the beginning and end of each session and between each change of sample. Another two Plešovice standards were measured between every $\sim 8-10$ unknown analyses. Three measurements of NIST SRM 612 glass were collected at the beginning of the analytical session with another two measurements collected at the end. In addition, the TEMORA 2 zircon (416.75 \pm 0.24 Ma, Black et al., 2004) was measured at the same intervals as the Plešovice zircon standard to qualitatively assess the accuracy of the data collected and to study the effects of laser drift and down-hole fractionation. LA-ICP-MS data were reduced using Iolite 2.5 (Paton et al., 2010, 2011) with the VizualAge data reduction scheme (Petrus and Kamber, 2012). This allowed the identification of any non-zircon grains or cases in which the laser continued firing into the underlying epoxy. Additionally, the program allowed for identification of the most appropriate down-hole fractionation model to be applied based on the signal behaviour of the Plešovice standards (in this case an exponential fit was applied). Laser drift was modelled against the Plešovice and secondary TEMORA 2 grains and this was used to produce a propagated error for each analysis.

Concordant apparent ages $<1200$ Ma were reported using the $\mathrm{U}^{238}$ / $\mathrm{Pb}^{206}$ isotopic system and those $>1200 \mathrm{Ma}$ were reported using the ${ }^{207} \mathrm{~Pb} /{ }^{206} \mathrm{~Pb}$ system (following the recommendation of Spencer et al., 2016). Data were omitted from further interpretation if they were obtained from a mixture of zircon and epoxy resin, non-zircon, or if their ages were discordant by either $\geq 10 \%$ (where the $\mathrm{U}^{238} / \mathrm{Pb}^{206}$ isotopic system was used) or $\geq 20 \%$ (where the ${ }^{207} \mathrm{~Pb} /{ }^{206} \mathrm{~Pb}$ system was used, due to higher errors associated with these analyses; Supplementary Data File 4).

The Isoplot R package (Vermeesch, 2018) was used for further calculations and data visualisation. Wetherill concordia plots (Wetherill, 1956) were used to display all concordant data for individual analyses (Supplementary Data File 5). Finally, histograms with kernel density estimation (KDE) were used to display the detrital zircon ages for samples in this study.

\section{Results}

\subsection{Raman spectroscopy heavy mineral analysis}

Twenty-two samples were measured for their heavy mineral contents using Raman Spectroscopy in this study (twenty-one from IODP 362 drill site U1480 and one from the middle Ayeyarwady River - MAG_17_26b), yielding a total of 34,765 accepted good and medium hits (Fig. 3; Supplementary Data File 2).

\subsubsection{IODP 362 drill site $U 1480$}

All samples from drill site U1480 record low amounts of ultrastable ZTR (zircon, tourmaline, and rutile) minerals averaging only a combined $4.4 \%$ of the heavy mineral population. With zircon being on average $0.5 \%$ of the population, tourmaline $2.7 \%$, and rutile $1.1 \%$. The low zircon counts, with eleven samples containing zero zircons, explains the poor zircon recovery for $\mathrm{U}-\mathrm{Pb}$ dating. There is only very little variation in the ZTR up-section, but an overall decrease from c. 10\% (362/U1480Q) to c. $5 \%(362 / \mathrm{U} 1480-002)$ can be observed (Fig. 3).

The largest population recorded in the heavy minerals is consistently amphibole, which averages $30.8 \%$ with little variation observed between the samples. The lowest recorded population is $16.4 \%$ in sample $362 / \mathrm{U} 1480-\mathrm{M}$ and the highest is $37.5 \%$ in sample 362/U1480-D (Fig. 3). The second largest consistent population is epidote, which averages $15.1 \%$. The population percentage rarely changes throughout the length of the core. The lowest population is $4.9 \%$ in sample $362 / \mathrm{U} 1480-004$ and the highest is $19.2 \%$ in sample $362 / \mathrm{U} 1480-\mathrm{G}$ (Fig. 3).

Garnet forms the third largest population averaging $11.8 \%$. There is 


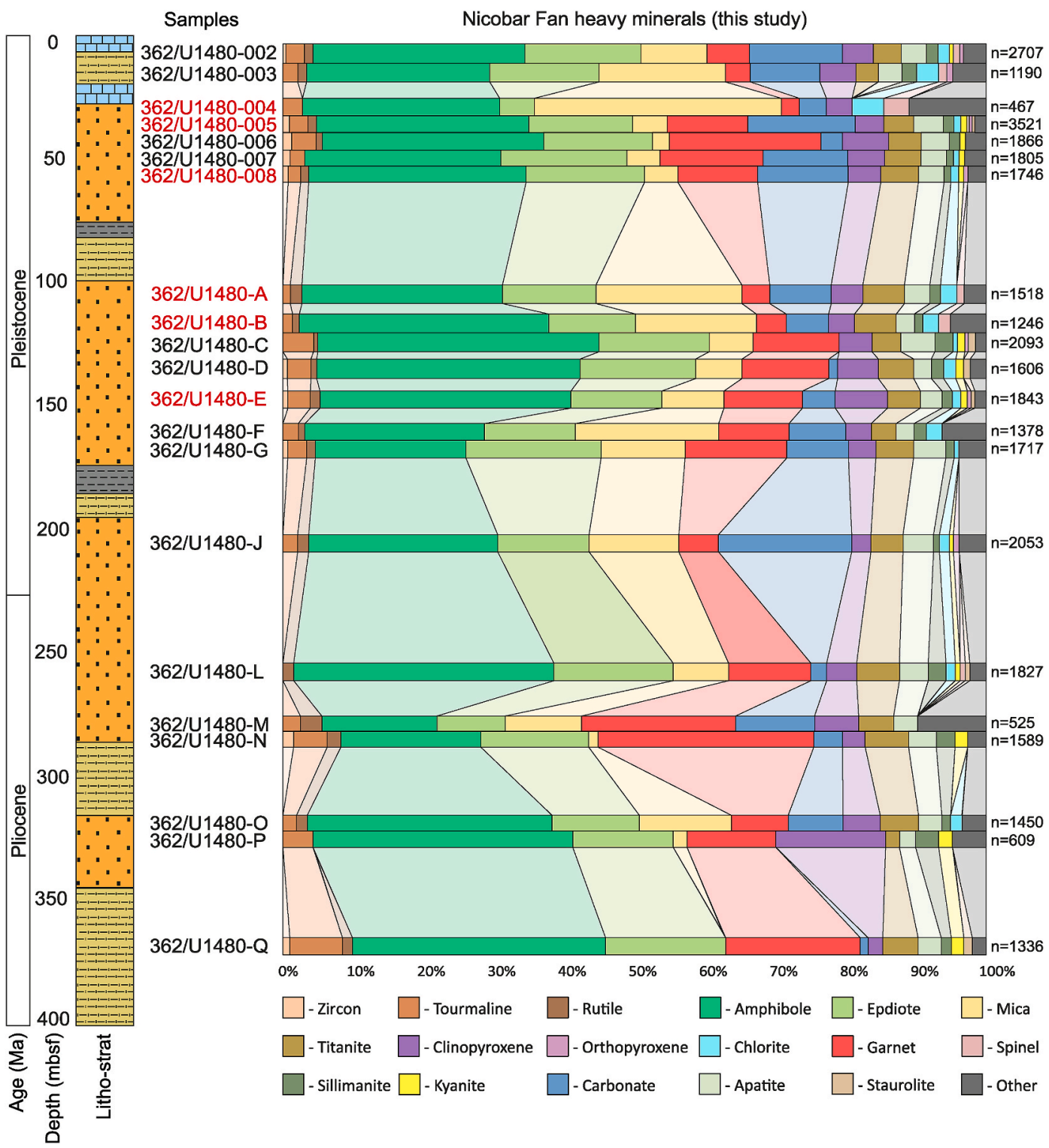

Fig. 3. Heavy mineral data for all IODP samples used in this study with their relative proportion of component minerals shown in \%. Samples are shown based on depth from deepest to shallowest, alongside their relative ages, and litho-stratigraphy (based on McNeill et al., 2017).

a notable reduction in the proportion of the garnet population from $19.2 \%$ at the base of the core to $6 \%$ at the top, with the highest proportion of $30.7 \%$ occurring in sample $362 / \mathrm{U} 1480-\mathrm{N}$ and the lowest $2.6 \%$ in sample $362 / \mathrm{U} 1480-004$ (Fig. 3). The final large population is mica minerals, which average $9.2 \%$. The mica population is quite variable, with the lowest population comprising $1.3 \%$ of sample $362 /$ U1480-N, and the largest $35.1 \%$ of sample 362/U1480-004 (Fig. 3).

The subordinate populations include dense carbonates, such as dolomite and rhodochrosite (average 8.18\%), clinopyroxene (average $4.7 \%$ ), titanite (average 4.7\%), apatite (average 3.6\%), sillimanite (average 1.6\%), chlorite (average 1.2\%), kyanite (average $0.7 \%$ ), spinel (average $0.3 \%$ ), orthopyroxene (average $0.3 \%$ ), and staurolite (average $0.3 \%$ ). Other heavy minerals make up $3.2 \%$ of the overall population (Fig. 3). Interestingly, all the ultrastable ZTR minerals would be categorised as subordinate populations.

\subsubsection{Middle Ayeyarwady River}

Sample MAG_17_26b from the middle course of the Ayeyarwady River yielded a total of 679 'good hit' heavy mineral Raman analyses (Supplementary Data File 2). This sample recorded very low amounts of ultrastable ZTR minerals with a combined $1.5 \%$ of the heavy mineral population (zircon - $0.9 \%$; tourmaline $-0.6 \%$; rutile $-0 \%$ ). The largest recorded heavy mineral populations are epidote and amphibole at $43.9 \%$ and $23 \%$, respectively. Garnet forms the third largest population at $20.8 \%$, with subordinate populations of titanite (2.7\%), clinopyroxene $(2.5 \%)$, orthopyroxene $(1.9 \%)$ apatite $(1.3 \%)$, staurolite $(0.7 \%)$, kyanite $(0.6 \%)$, spinel $(0.3 \%)$. Other heavy minerals make up the final $0.9 \%$ of the overall population.

\section{2. $U-P b$ zircon geochronology}

A total of six Plio-Pleistocene samples from IODP 362 drill site U1480 were analysed for their U-Pb spectra (362/U1480-004, -005, -008, -A, $-B,-E,-X)$. As shown from the Raman Spectroscopy these samples are relatively zircon poor, a total of 363 zircons were analysed with 246 concordant ages obtained from all samples. There is little to no change in $\mathrm{U}-\mathrm{Pb}$ zircon spectra among the samples and their characteristic age peaks are discussed here together. The youngest detrital age obtained from these samples was $14.8 \mathrm{Ma}(362 / \mathrm{U} 1480-008)$ with the oldest being $2848 \mathrm{Ma}(362 / \mathrm{U} 1480-\mathrm{X}$; Supplementary Data File 4). Five distinct age 
peaks can be identified from these samples (Fig. 4a): 1) 0-150 Ma (31 analyses); 2) 200-350 Ma (13 analyses); 3) 400-650 Ma (57 analyses); 4) $750-1200 \mathrm{Ma}$ (88 analyses); 5) 1550-1900 Ma (37 analyses). Other ages present include Devonian-Carboniferous, Meso-Proterozoic, and Archean-Palaeo-Proterozoic (Fig. 4a).

\section{Discussion}

Previous $\mathrm{U}-\mathrm{Pb}$ zircon studies on the sedimentary provenance of the Nicobar and Bengal fans indicate the Himalaya (specifically the GHS, THS, and Gangdese Arc) as the dominate sediment source into the fans throughout the Cenozoic (Ingersoll and Suczek, 1979; McNeill et al., 2017; Blum et al., 2018; Pickering et al., 2020b) with additional input
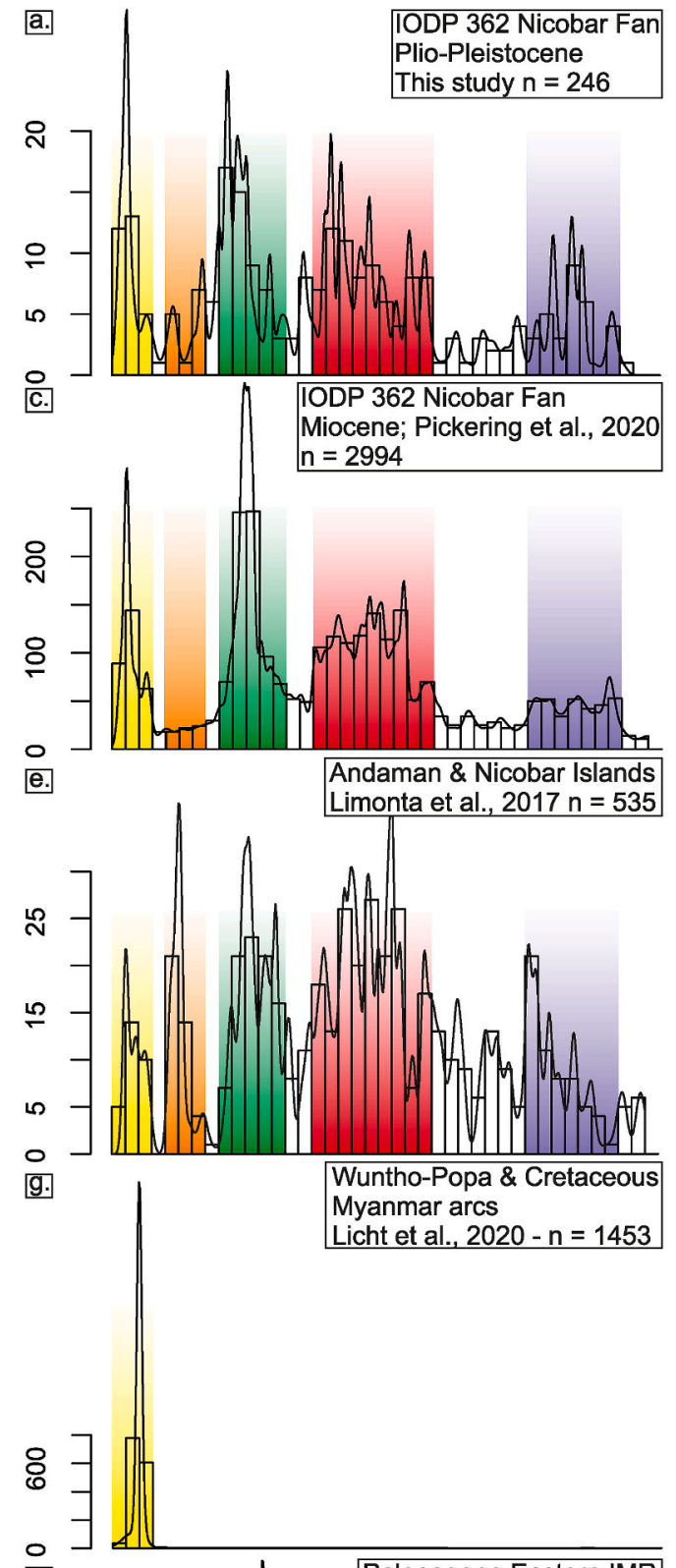

i.
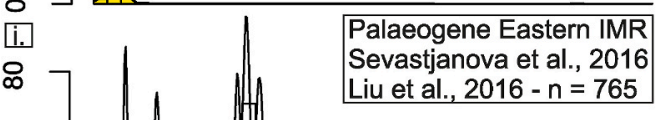

운

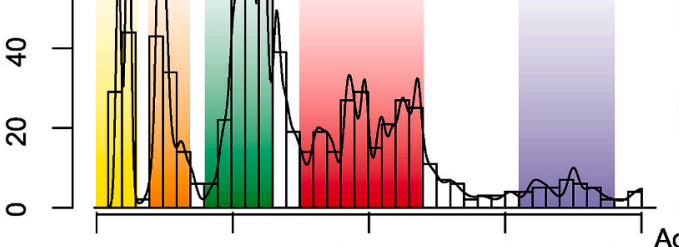

0

500

1000

1500

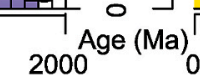

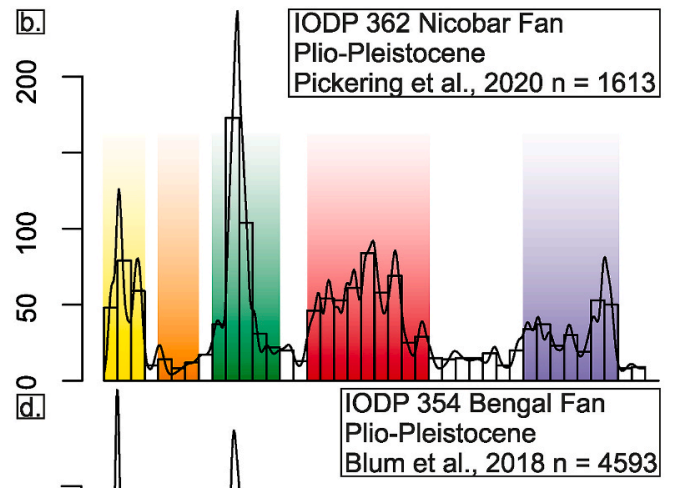
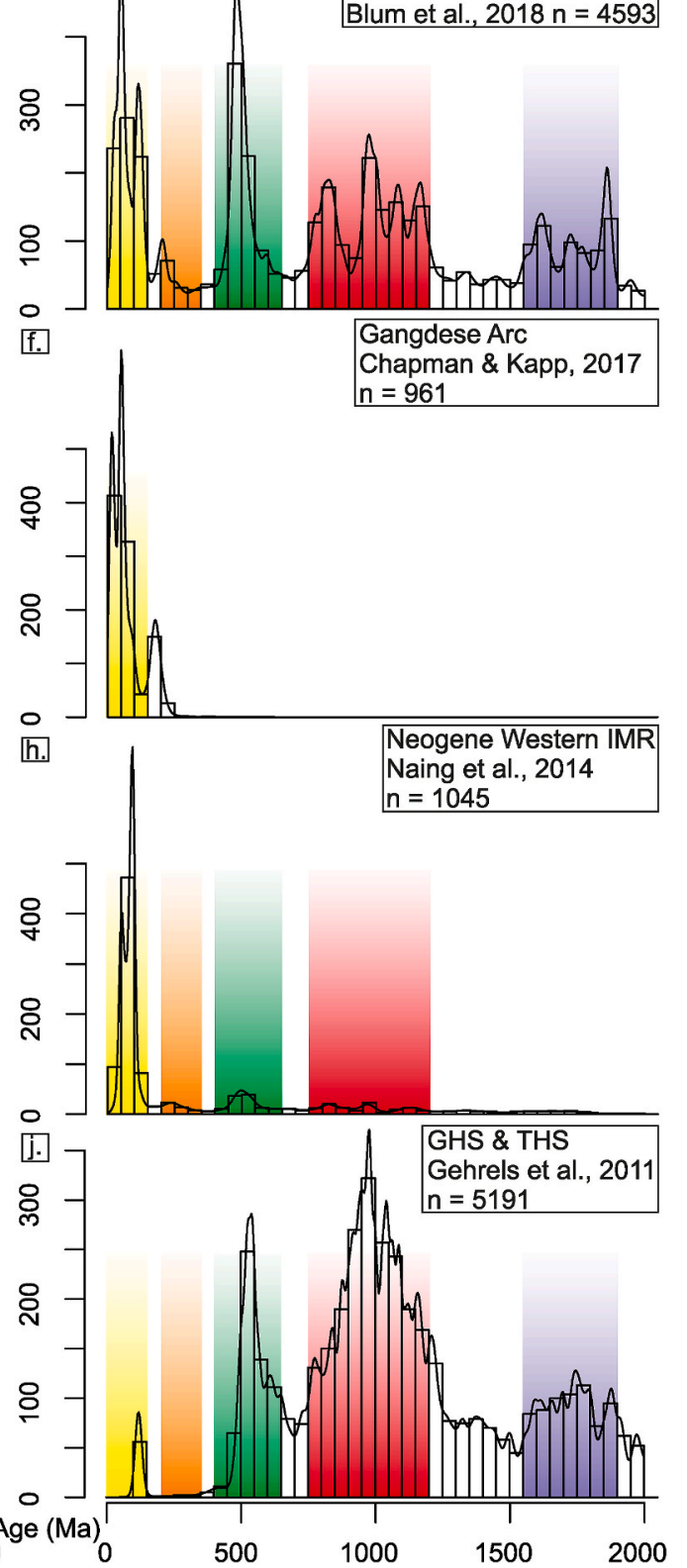

Fig. 4. Histograms with KDEs showing all $\mathrm{U}-\mathrm{Pb}$ zircon data used in this study as well as comparisons with other regional studies. a) All concordant $\mathrm{U}-\mathrm{Pb}$ zircon data for Plio-Pleistocene samples from IODP 362 drill site U1480 used in this study. b) U-Pb zircon data for PlioPleistocene samples from IODP 362 drill site U1480 (Pickering et al., 2020b) c) $\mathrm{U}-\mathrm{Pb}$ zircon data for Miocene samples from IODP 362 drill site U1480 (Pickering et al., 2020b). d) U-Pb zircon data for Plio-Pleistocene samples from IODP 354 in the Bengal Fan (Blum et al., 2018). e) U-Pb zircon data for Oligocene sandstones from the Andaman and Nicobar Islands (Limonta et al., 2017). f) $\mathrm{U}-\mathrm{Pb}$ zircon data from the Gangdese Arc (Chapman and Kapp, 2017 and references therein). g) $\mathrm{U}-\mathrm{Pb}$ zircon data from Wuntho-Popa and Cretaceous Myanmar arcs (Licht et al., 2020 and references therein). h) U-Pb zircon data from the Neogene Western Indo-Myanmar Ranges (Naing et al., 2014). i) U-Pb zircon data from the Palaeogene Eastern Indo-Myanmar Ranges (Sevastjanova et al., 2016; Liu et al., 2016). j) U-Pb zircon data for samples from the Greater and Tethyan Himalayan sequences (Gehrels et al., 2011 and references therein). Comparison bars show the different age populations identified in this study; yellow $=0-150 \mathrm{Ma}$; orange $=200-350 \mathrm{Ma}$; green $=400-650 \mathrm{Ma}$; red $=750-1200$ Ma; purple $=1550-1900$ Ma. . (For interpretation of the references to colour in this figure legend, the reader is referred to the Web version of this article.) 
from surrounding sources such as the IMR (McNeill et al., 2017). However, whilst the U-Pb zircon spectra from this study largely supports these sources of detrital zircon, the more extensive heavy mineral data indicates that the provenance of many minerals in the Plio-Pleistocene Nicobar Fan may be more complex than this with evidence for a higher degree of source mixing.

\section{1. $U-P b$ detrital zircon studies}

The detrital zircon spectra from the samples analysed in this study are comparable to those found in larger studies on the Miocene to Pleistocene samples of the Nicobar Fan (McNeill et al., 2017; Pickering et al., 2020b), Plio-Pleistocene samples from the Bengal Fan (Blum et al., 2018), and Oligocene samples from the Andaman and Nicobar Islands (Limonta et al., 2017). Most of which share the five key age peaks identified in this study (0-150 Ma, 200-350 Ma, 400-650 Ma, 750-1200 Ma, and 1550-1900 Ma; Fig. 4a-e), with only the 200-350 Ma noticeably absent from the Miocene Nicobar Fan (Fig. 4c). Potential magmatic and metamorphic sources for these zircons include previously proposed sources in the GHS and THS (400-650 Ma, 750-1200 Ma, and 1550-1900 Ma; Fig. 4j), and the Gangdese Arc (0-150 Ma; Fig. 4f), along with additional sources of the same age that have not been previously investigated, such as the Wuntho-Popa and Cretaceous Myanmar arcs (0-150 Ma; Fig. 4g) and the IMR (0-150 Ma, 200-350 Ma, 400-650 Ma, and 750-1200 Ma; Fig. 4h and i).

\subsubsection{Sources of zircon}

The Himalayan sequences (THS and GHS) and Gangdese Arc have been previously proposed as sources of zircon into the Miocene to Pleistocene Nicobar Fan (e.g., McNeill et al., 2017; Pickering et al., 2020b) and are likely good candidates for sourcing detrital zircons into the samples of this study. The THS represents a series of Neo-Proterozoic to Cretaceous marine clastic and carbonate rocks exposed in the frontal and higher Himalaya (Brookfield, 1993; Garzanti, 1999; Gehrels et al., 2006, 2011). They overlie the GHS metamorphic basement and formed along the southern margin of the Tethys during periods of Late Proterozoic, Palaeozoic, and Mesozoic rifting (Gaetani and Garzanti, 1991; Brookfield, 1993; Garzanti, 1999; Hu et al., 2010). The U-Pb detrital zircon spectra of the combined GHS and THS is dominated by pre-Cambrian ages, with significant populations in the Neo-Proterozoic, the Meso-Proterozoic, the Palaeo-Proterozoic, and the Archean (Gehrels et al., 2011, Fig. 4j). These populations correspond directly to the 400-650 Ma, 750-1200 Ma, and 1550-1900 Ma age peaks in the samples from this study (Fig. 4a), other samples from the Nicobar Fan (McNeill et al., 2017; Pickering et al., 2020b), and those from the Plio-Pleistocene Bengal Fan (Blum et al., 2018). The Gangdese Arc forms part of the larger Transhimalayan Batholith and is located in the Lhasa Terrane in southern Tibet, the arc is dominated by I-type granitoids formed during the northwards subduction of Neo-Tethys beneath the Lhasa Terrane ( $\mathrm{Ji}$ et a., 2009). These granitoids formed in four distinct phases between $\sim 200$ and $40 \mathrm{Ma}$ (Ji et al., 2009) and have been interpreted as a major source of zircons of this age into the Bengal and Nicobar fans (McNeill et al., 2017; Blum et al., 2018; Pickering et al., 2020b). Neogene leucogranites found in the THS, GHS, and southern Tibet have been inferred as a potential source of zircons younger than $40 \mathrm{Ma}$ found in the detrital spectra of the Bengal Basin and Nicobar Fan (Schärer et al.., 1986; Najman et al., 2008, 2019; Pickering et al., 2020b).

Other more proximal sources such as the IMR, Wuntho-Popa and Cretaceous Myanmar arcs, and the ANAR that have not previously been proposed as sources of zircon into the Nicobar Fan also contain zircon age populations comparable to those of this and other studies (Fig. $4 \mathrm{a}-\mathrm{c}$ ). The IMR is a N-S trending mountain belt in western Myanmar formed of Mesozoic-Cenozoic accretionary wedge sediments and ophiolites (United Nations, 1979; Mitchell et al., 2010) that have seen significant uplift between the middle Eocene and early Miocene
(Zhang et al., 2018; Licht et al., 2019; Gough et al., 2020; Najman et al., 2020). This mountain range formed as a fold and thrust system related to oblique collision between the Indian Plate and the Myanmar Microplate (Mitchell, 1993; Rangin et al., 2013; Rangin, 2017, 2018) and are divided into an outer Neogene western belt and an inner Late Cretaceous to Palaeogene eastern belt (United Nations, 1979; Maurin and Rangin, 2009; Mitchell et al., 2010). The Neogene western belt is almost entirely dominated by zircons of $0-150 \mathrm{Ma}$ (Fig. 4h), in contrast, the Palaeogene eastern belt displays a more varied spectra of ages with pre-Cambrian ages broadly comparable to the GHS \& THS, but crucially containing a Permo-Triassic age peak that is not typical of the Himalayan signature but is partially recorded in the Plio-Pleistocene Nicobar Fan (Fig. 4).

These 200-350 Ma zircon ages are a common feature of sediments in Sibumasu and Indochina and are sourced from granitoids of the Permo-Triassic SE Asia tin belt (Cobbing et al., 1992; Hall and Sevastjanova, 2012; Sevastjanova et al., 2016). The presence of Permo-Triassic zircons in the Plio-Pleistocene Nicobar Fan, even if in relatively small quantities, suggests the recycling of sediment through the eastern IMR and into the Nicobar Fan.

The 0-150 Ma zircon ages prevalent in the IMR are dominantly derived from Cretaceous granites of the Myanmar Arc (Gardiner et al., 2018) and magmatism in the Wuntho-Popa Arc (Gardiner et al., 2018; Zhang et al., 2018; Licht et al., 2020). Cretaceous to recent magmatism within the Myanmar Arc, as well as recycling from the IMR, have been proposed as potential sources of $0-150$ Ma zircons to Oligocene Sandstones in the Andaman Islands (Allen et al., 2008a; Limonta et al., 2017) and Miocene deposits of the Nicobar Fan (McNeill et al., 2017). Given the comparable ages found in samples from this study, it is likely that metamorphic and magmatic activity in the IMR and Cretaceous Myanmar/Wuntho-Popa arc represent sources of 0-150 Ma zircons into Plio-Pleistocene deposits of the Nicobar Fan alongside the previously proposed Gangdese Arc source (Fig. 4).

The combined contribution of sediment from both the Himalaya and IMR into the Nicobar Fan is further supported by the detrital zircon spectra of the ANAR (Fig. 4e). The ANAR consists of two distinct geological terranes, the North Andaman Island along with the eastern coasts of Middle and South Andaman are formed of chaotically thrusted ophiolites and pelagic sediments formed in the Late Cretaceous to Paleocene (Pedersen et al., 2010; Pal, 2011; Bandopadhyay, 2012). In contrast, the western coasts of Middle and South Andaman along with Nicobar Island are formed of Oligocene siliciclastic turbidites of the Andaman Flysch. The Andaman Flysch is thought to have been accreted during oblique subduction of the Indian Plate and is derived from both the Himalaya and the IMR, with U-Pb zircon data comparable to both the Bengal Fan and the modern Ayeyarwady River (Allen et al., 2008a; Limonta, 2017). The Oligocene sandstones of the Andaman Flysch show similar U-Pb detrital zircon spectra to those of this study (0-150 Ma, 200-350 Ma, 400-650 Ma, 750-1200 Ma, and 1550-1900 Ma age peaks; Fig. 4e) and may share sources for zircons of these ages (e.g., the Himalaya and IMR).

Finally, Plio-Pleistocene sediments of the Bengal Fan also record the 0-150 Ma age peak observed in our samples and those from the IMR (Fig. 4d). Whilst some Miocene and younger zircons exist in both the Bengal Fan dataset and those from this study (interpreted to have been derived from post-Miocene exhumation in the Eastern Himalayan Syntaxis - Booth et al., 2009; Blum et al., 2018), the vast majority in both datasets are in the 50-150 Ma age range corresponding directly to the age of magmatism in the Cretaceous-Palaeogene arcs that extend through the eastern Himalaya and down into Myanmar (including the Gangdese, Cretaceous Myanmar, and Wuntho-Popa arcs; e.g., Wang et al., 2014).

\subsection{Heavy minerals}

Previous optical heavy mineral studies of the Miocene to Pleistocene Nicobar Fan (e.g., McNeill et al., 2017; Pickering et al., 2020b) are 
comparable to those of our study with dominant amphibole-epidote-garnet assemblages and low ZTR ratios (Fig. 5). Pickering et al. (2020b) reports changes in the heavy mineral concentrations between the Miocene and Pleistocene Nicobar Fan, with a down-section decrease in amphibole and increases in epidote and ZTR. These authors suggest that whilst diagenetic processes (e.g., Garzanti et al., 2019) can produce decreases in amphibole they are unlikely the cause for the observed heavy mineral assemblages in the Nicobar Fan, instead proposing that changes in provenance and hydraulic-sorting processes are the likely cause, with metamorphic detritus from the GHS proposed as a major source of these minerals (Pickering et al., 2020b). Here we further test this with comparison of the heavy mineral compositions of multiple candidate sources (including the Himalaya, IMR, and ANAR) to better understand the sedimentary provenance of the Nicobar Fan.

Sediments in the Plio-Pleistocene Bengal Basin (Uddin et al., 2007; Najman et al., 2012) and modern-day coastal Bay of Bengal (Garzanti et al., 2013) are thought to be derived from a combination of the Himalaya (via the Ganga river system), the Eastern Himalayan Syntaxis (via the Brahmaputra River System), and the IMR (via the Meghna River System) and show variably comparable heavy mineral percentages to those from this study (Fig. 5). The Plio-Pleistocene deposits from the Bengal Basin contain more ultrastable and metamorphic minerals (e.g., kyanite, sillimanite, staurolite) than our samples, consistent with their derivation from the continental Himalaya, they are however the only heavy mineral assemblage found in our comparisons to report and display large percentages of mica (Fig. 5). Modern-day sediments from the Bengal Coast again show greater input from metamorphic minerals than our samples, but the majority of their heavy mineral percentages are comparable (low ZTR, high amphibole, epidote, and garnet; Fig. 5). The input of abundant metamorphic detritus into the Bengal Basin is likely the result of the re-routing of the Brahamputra and Meghna rivers into the catchment zones of the Eastern Himalayan Syntaxis and IMR, respectively, recording the Miocene to recent uplift observed in these regions (Booth et al., 2009; Bracciali et al., 2015; Najman et al., 2016, 2020).

The heavy mineral composition of Eocene to Miocene sediments of the western IMR is not directly comparable to those from this study (Allen et al., 2008b; Naing et al., 2014, Fig. 5). Neogene sediments of the western IMR display high concentrations of ultrastable ZTR minerals ( $40 \%$; Fig. 5) along with significant populations of epidote, apatite, garnet, and chrome spinel (Allen et al., 2008b; Naing et al., 2014). These compositionally mature Neogene sediments are interpreted to have been derived from either a mixture of continental arc (the Cretaceous Myanmar Arc) and accreted ophiolite material (Naing et al., 2014) or from a dominant Himalayan source along with minor recycling from the Cretaceous to Palaeogene eastern IMR (Allen et al., 2008b). This is in contrast to amphibole-epidote-garnet dominant samples from the Plio-Pleistocene Nicobar Fan (Fig. 5). This suggests that, whilst the 0-150 Ma zircon ages and heavy mineral populations may have been ultimately derived from the Myanmar Arc and Cretaceous to Palaeogene eastern IMR, it is likely unlikely that Neogene deposits of the western IMR have been eroding and providing large quantities of sediment directly into the Nicobar Fan throughout the Plio-Pleistocene.

However, that does not exclude the Cretaceous-Palaeogene eastern

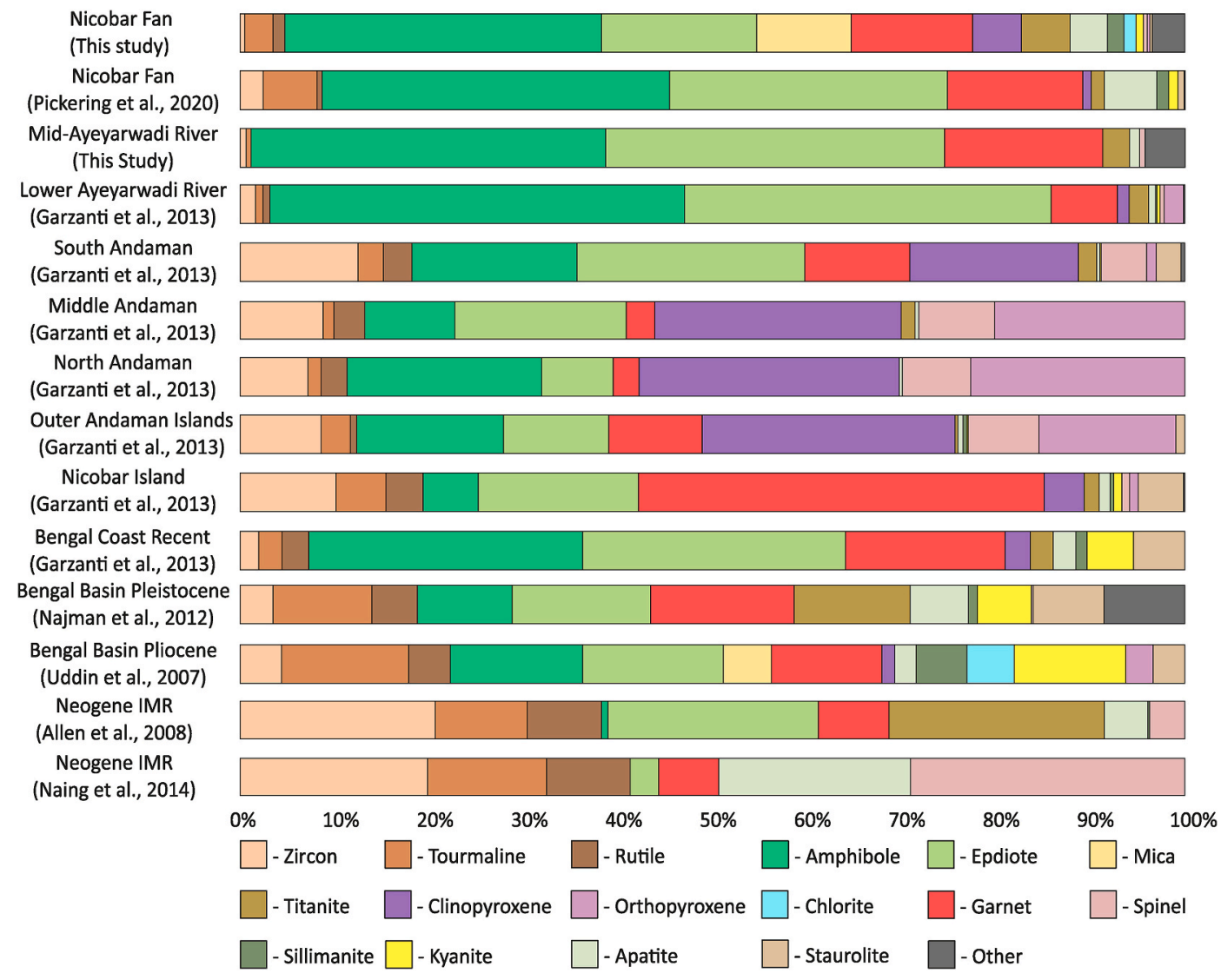

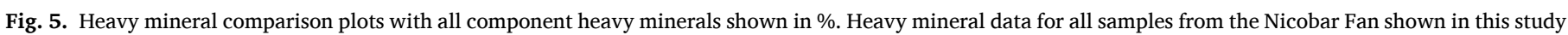

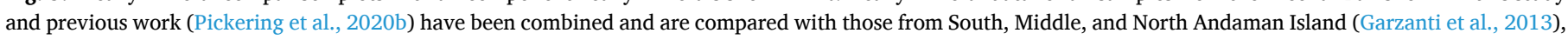

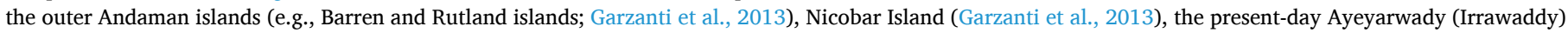

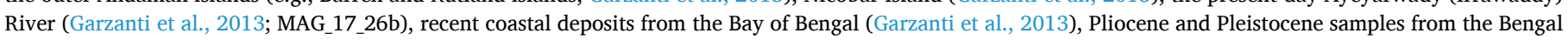

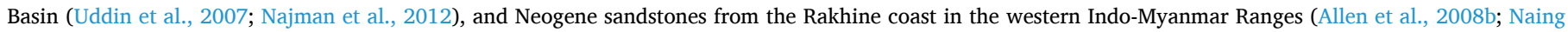
et al., 2014). 
belt of the IMR as a direct source of heavy minerals into the Nicobar Fan. Modern-day sediments from both the Andaman-Nicobar Islands and the Ayeyarwady River are sourced from the eastern IMR (Garzanti et al., 2013; Limonta et al., 2017) and display comparable heavy mineral populations to the Plio-Pleistocene Nicobar Fan (Fig. 5), as does sample MAG_17_26b of this study from the Mid-Ayeyarwady River (Fig. 5). Samples from both the middle and lower Ayeyarwady River contain low abundances of ultrastable ZTR minerals, as well as high percentages of both amphibole and epidote (Garzanti et al., 2013; MAG_17_26b; Fig. 5). This, along with subordinate populations of garnet, clinopyroxene, and titanite, plus a dominate 0-150 Ma peak in its detrital zircon spectra (Garzanti et al., 2013), make the Ayeyarwady River a compelling potential source of sediment to the Plio-Pleistocene Nicobar Fan.

The heavy mineral composition of sediments in the Plio-Pleistocene Nicobar Fan can also be correlated with modern-day beach and river sand deposits throughout the Andaman-Nicobar Islands (Fig. 5). As a whole, sands from the Andaman-Nicobar Islands contain more ultrastable ZTR minerals (up to $\sim 20 \%$ ) than those of the Plio-Pleistocene Nicobar Fan, indicating that the samples from this study are more compositionally immature than sands of the accretionary wedge and ophiolite dominated Andaman-Nicobar Islands (Fig. 5). Populations of amphibole, epidote, garnet, and clinopyroxene are common among the samples from this study and the North, South, Middle, and outer Andaman Islands (Fig. 5). Whilst our samples lack the larger populations of orthopyroxene and spinel observed in the North, Middle, and outer Andaman Islands; sands from South Andaman Island are comparatively lacking in these minerals and correlate best with those of our study (Fig. 5). In addition, the presence of up to $40 \%$ garnet in modern beach sands from the South Andaman and Nicobar Islands is interpreted as coming initially from Himalayan-derived Miocene sediments in the eastern Bengal Fan that have since been accreted and recycled through the Andaman Flysch (Garzanti et al., 2013). Final uplift of the ANAR since the Pliocene (Allen et al., 2008a) may have played a role in delivering sediment from the Andaman Flysch (containing recycled Himalayan and IMR material) into the Plio-Pleistocene Nicobar Fan. Recent apatite fission track studies from the Nicobar Fan (Pickering et al., 2020b) rule out any significant intermediate storage of apatite between erosion from the source and deposition in the fan. Although, they do point towards rapid exhumation rates in the Plio-Pleistocene consistent with recent uplift in the IMR, ANAR, and eastern Himalaya (Booth et al., 2009; Allen et al., 2008a; Najman et al., 2020).

Finally, the abundance of amphibole in the Plio-Pleistocene Nicobar Fan (Fig. 5) may indicate input from intermediate volcanism in the Sunda Arc, which has been active throughout the Cenozoic (Hall, 2012), either through ash-fall deposits or uplift and erosion. While only limited arc-derived ash layers are reported from Miocene samples of the Nicobar Fan (McNeill et al., 2017; Pickering et al., 2020a, b), an increase in volcanic ash beds is observed in drill core from U1480 at shallower depths (particularly in intervals 0-26 mbsf and 26-1250 mbsf; Pickering et al., 2020a-b; Fig. 2a) suggesting an increase in arc-derived material into the Pleistocene (Plio-Pleistocene samples from this study were drilled between 0 and $400 \mathrm{mbsf}$ ). Interestingly, an increase in volcanic ash layers in the Pleistocene is also observed at drill site U1443 of IODP leg 353 in the Ninety-East Ridge (Clemens et al., 2016). Derivation of volcanic ash layers and abundant amphibole from the Sunda Arc is supported by the observation of a major increase in volcanism in the High Barisan Mountains of Sumatra in the Plio-Pleistocene (De Smet and Barber, 2005), the increased westwards delivery of volcanogenic sediments into the forearc region of northern Sumatra during the Plio-Pleistocene (Harbury and Kallagher, 1991), and the onset of volcanism at Barren Island, in the Andaman Sea, at 1.8 Ma (Ray et al., 2013).

\subsection{Sediment routing}

Whilst multiple submarine channels once connected the Bengal and
Nicobar Fans prior to their shut-down by the northwards drifting NinetyEast Ridge and Indian Plate only one submarine channel now remains linking the Bengal and Nicobar Fans (Jena et al., 2016; Pickering et al., 2020a). Channel E7 begins in the north-eastern side of the Bengal Fan adjacent to the IMR and may have delivered sediments into the Plio-Pleistocene deposits of the Nicobar Fan through the thin gateway remaining prior to final collision of the Ninety-East Ridge (Fig. 6). Potential sources of sediment along this channel that can be correlated with the heavy mineral and U-Pb zircon data from the Plio-Pleistocene Nicobar Fan include; the eastern Bay of Bengal (including sediment shed off the Himalaya), the uplifting eastern IMR, the Ayeyarwady River Delta (following westwards propagation across the shelf), and sediment shed westwards off the ANAR. The comparatively low morphological expression of the trench west of the Andaman-Nicobar Islands (less than 3000 m deep; Hall, 2012; Jena et al., 2016) suggests that sediment could have crossed the trench axis and been deposited in the Nicobar Fan (e.g., Moore et al., 1982). In fact, further channels and fans crossing the trench axis have been identified along its length and may have provided additional material into the Nicobar Fan (Moore et al., 1982). These include a large sediment slide (transporting over $900 \mathrm{~km}^{3}$ material) offshore western Myanmar that transported sediment across the trench from a Pleistocene lobe of the Ayeyarwady River Delta (Moore et al., 1976; Moore et al., 1982, Fig. 6).

A recent study on $\mathrm{Sr}-\mathrm{Nd}$ isotopic data for Nicobar Fan sediments shows that the youngest Pleistocene samples show less radiogenic values (lower ${ }^{87} \mathrm{Sr} /{ }^{86} \mathrm{Sr}$ and higher $\varepsilon_{\mathrm{Nd}}$; Unit I of Chen et al., 2020) then their Pliocene, Miocene, and older counterparts (e.g., Units II \& III of Chen et al., 2020). These Pleistocene samples show a greater affinity in their isotopic ratios to samples from the IMR, Myanmar Arc, Ayeyarwady River, and Surma Basin than the Greater or Tethyan Himalaya sources invoked for older samples (Chen et al., 2020). The authors of that study suggest that delivery of sediment from the IMR or Cretaceous Myanmar Arc via the Ayeyarwady River into the Nicobar Fan would not be possible due to the development of the Martaban Basin (e.g., Racey and Ridd, 2015). However, as previously discussed, there is clear evidence that western lobes of the Ayeyarwady have been capable of delivering sediment across the trench and into the fan system since at least the Pleistocene (e.g., Moore et al., 1976; Moore et al., 1982).

Finally, the stark comparison between heavy mineral populations observed in this study and those of the Ayeyarwady River and nearby ANAR are consistent with inferences that can be made about the transport distances of these sediments. The heavy mineral populations from samples in the study are compositionally incredibly immature and they lack large populations of ultrastable ZTR minerals $(<10 \%)$ that are usually indicative of long transport distances and derivation from a continental setting. Instead they contain significant populations of amphibole $(\sim 30 \%)$, apatite $(\sim 15 \%)$, garnet $(\sim 12 \%)$, and mica $(\sim 9 \%)$. Amphibole (along with pyroxene and titanite which are also present in these samples) is among the most unstable of the heavy minerals during weathering, transport, and burial, whilst apatite and garnet are also moderately unstable during weathering conditions (Morton, 1984; Morton \& Hallsworth, 1999, 2007). This suggests that for large populations of these minerals to be present within Plio-Pleistocene samples in the Nicobar Fan the majority of contributing sediments are unlikely to have been transported long distances from the source (Morton, 1984; Morton \& Hallsworth, 1999, 2007), such as they would be had they been shed directly off the Himalaya $(\sim 3000 \mathrm{~km})$. Only the ultrastable minerals (e.g., ZTR) and moderately stable (e.g., epidote, garnet) can have travelled such a distance (Table 1). Whilst comparable populations of low-stability and compositionally immature heavy minerals have been reported from the Indus and Bengal fans where the Himalaya have been interpreted as the only reasonable source following diverse hydraulic-sorting processes (France-Lanord et al., 2016; Garzanti et al., 2020), the Nicobar Fan represents a case where complex local arc- and accretionary wedge-dominated geology can contribute to the delivery of low-stability immature heavy mineral assemblages into the fan. Here 


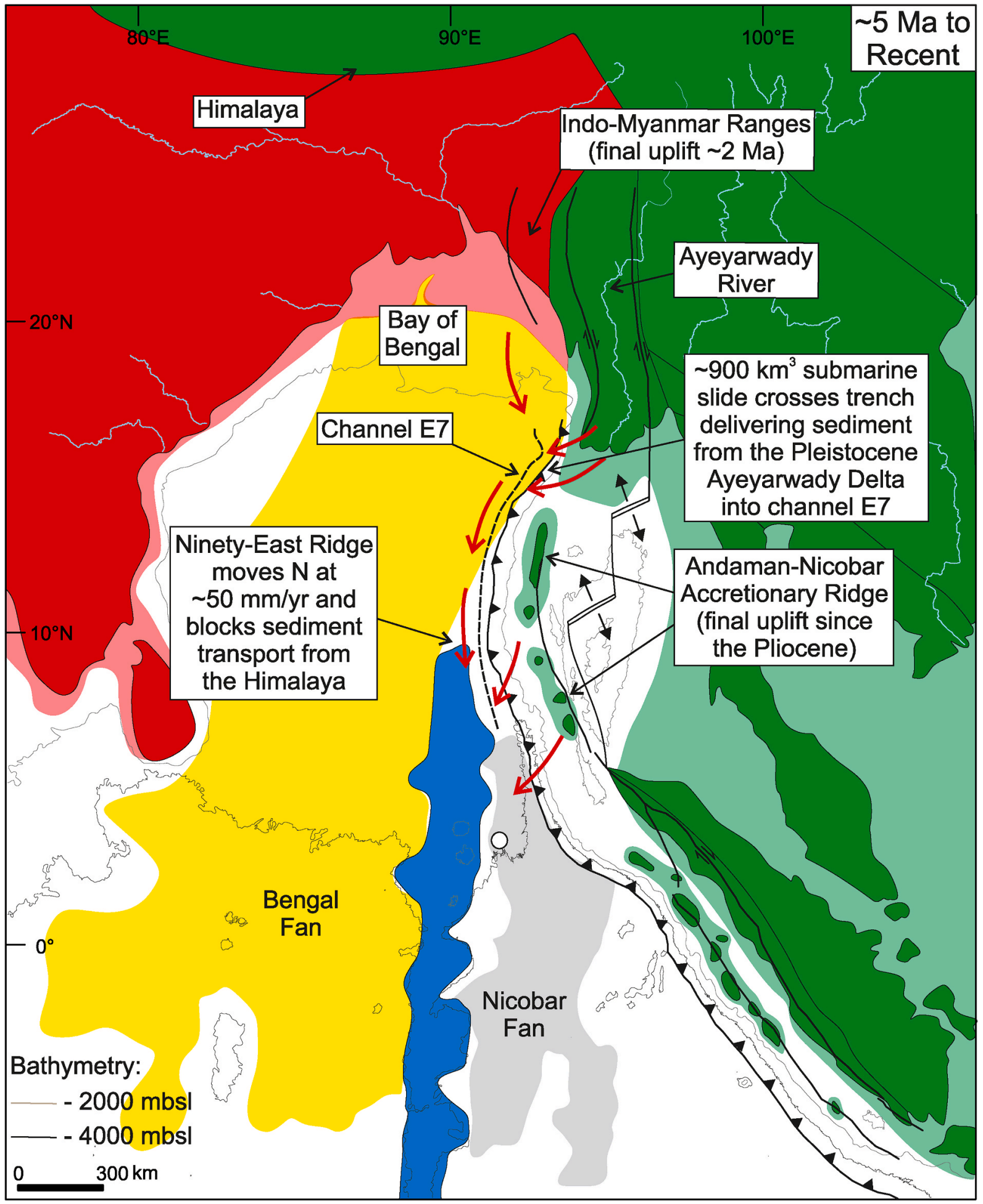

Fig. 6. Tectonic setting and sediment routing pathways for the area surrounding the Nicobar Fan from $\sim 5$ Ma to Recent. The figure shows how the northwards movement of the Ninety-East Ridge (shown in blue) over the last 5 Ma has shut down transport of sediment into the Nicobar Fan (velocity of the Indian Plate is taken from White and Lister, 2012). Red arrows show sediment routing pathways from the IMR and Ayeyarwady River via channel E7 of the Bengal Fan from the north (Jena et al., 2016) and the Andaman-Nicobar Ridge from the west (uplift for the IMR and ANR to present elevations was complete by the Pleistocene; Allen et al., 2008a; Najman et al., 2020). The location of tectonic structures and plates are from Hall (2012); block colours (red and green) represent land masses whilst faded colours (light red and light green) depict shallow marine settings along the continental shelf. The feature in yellow shows the locations of high sediment accumulation rates into the present-day Bengal Fan (taken from Pickering et al., 2020a). . (For interpretation of the references to colour in this figure legend, the reader is referred to the Web version of this article.) 
Table 1

Table showing the most abundant heavy minerals found in Plio-Pleistocene samples in this study, their relative stability *based on Morton (1984), and their potential source regions. IMR = Indo-Myanmar Ranges, ANAR = Andaman-Nicobar Accretionary Ridge, GHS = Greater Himalayan Sequences, THS = Tethyan Himalayan Sequences.

\begin{tabular}{|c|c|c|c|}
\hline $\begin{array}{l}\text { Heavy } \\
\text { mineral }\end{array}$ & $\begin{array}{l}\text { Average } \\
\text { percentage }\end{array}$ & $\begin{array}{l}\text { Relative } \\
\text { stability* }\end{array}$ & Potential sources \\
\hline Amphibole & $30.8 \%$ & Unstable & $\begin{array}{l}\text { Palaeogene IMR, Ayeyarwadi } \\
\text { River, ANAR, Sunda Arc }\end{array}$ \\
\hline Epidote & $15.1 \%$ & $\begin{array}{l}\text { Moderately } \\
\text { stable }\end{array}$ & $\begin{array}{l}\text { Palaeogene IMR, Ayeyarwadi } \\
\text { River, Eastern Himalayan } \\
\text { Syntaxis }\end{array}$ \\
\hline Garnet & $11.8 \%$ & $\begin{array}{l}\text { Moderately } \\
\text { stable }\end{array}$ & $\begin{array}{l}\text { ANAR (Nicobar Island), } \\
\text { Eastern Himalayan Syntaxis }\end{array}$ \\
\hline Clinopyroxene & $4.7 \%$ & $\begin{array}{l}\text { Ultra- } \\
\text { unstable }\end{array}$ & ANAR (Andaman Islands) \\
\hline Titanite & $4.7 \%$ & Unstable & Neogene IMR, ANAR \\
\hline ZTR & $4.4 \%$ & Ultrastable & $\begin{array}{l}\text { GHS, THS, Eastern Himalayan } \\
\text { Syntaxis, Palaeogene IMR }\end{array}$ \\
\hline Apatite & $3.6 \%$ & Unstable & Neogene IMR \\
\hline
\end{tabular}

proximal regions, where comparable heavy mineral assemblages have been identified, such as the eastern IMR and Ayeyarwady River $(\sim 2000$ $\mathrm{km})$ or the ANAR $(\sim 1000 \mathrm{~km})$, are more likely sources for these low-stability minerals (Fig. 6; Table 1).

\section{Conclusions}

The detrital zircon spectra of Plio-Pleistocene samples of the Nicobar Fan from this study are consistent with previous studies on the sediments of the Nicobar and Bengal fans indicating that the original magmatic and metamorphic sources of these zircons can be found within the Greater and Tethyan Himalayan sequences, the Gangdese or Transhimalayan arcs, and the Indo-Myanmar Ranges. However, the heavy mineral data presented here indicate that a large proportion of PlioPleistocene sediments in the Nicobar Fan have been derived from a more complex array of sources. The comparative lack of metamorphicderived heavy minerals (e.g., kyanite and sillimanite) and the low percentage of ZTR minerals within the Nicobar Fan $(<10 \%)$ is in contrast to Himalayan-derived sediments in the Bengal Basin and indicates that erosion from the Himalayan-sequences is unlikely to be the sole contributor of sediment into the Plio-Pleistocene Nicobar Fan. This is coupled with the abundance of low- and moderate-stability minerals in the samples from this study (e.g., amphibole, apatite, clinopyroxene, epidote, garnet), which cannot have been transported large distances, and suggests that proximal sources have most likely delivered a greater percentage of the lower stability heavy minerals into the Nicobar Fan than previously reported. Likely proximal candidates for the delivery of low-stability heavy minerals into the Nicobar Fan during the PlioPleistocene are, the ANAR (comprising both accreted Bengal Fan sediments and ophiolitic material) and the eastern IMR (including delivery via the Ayeyarwady River), based their on increased rates of uplift throughout the Plio-Pleistocene and comparable heavy mineral populations to those presented in this study. The large-scale delivery of Himalayan-derived material into the Nicobar Fan throughout the Miocene and Pliocene would have gradually decreased with the northern advance of the Ninety-East Ridge during the Plio-Pleistocene with sediment instead shedding off the uplifting IMR and ANAR. Finally, this study shows that Plio-Pleistocene sediments in the Nicobar Fan may represent an important record of Plio-Pleistocene uplift and erosion of the northern Sunda Arc from Myanmar to Sumatra, alongside the previously reported record of Pliocene and older erosion in the eastern Himalayan.

\section{Credit author statement}

Max Webb: Conceptualization, Formal analysis, Investigation, Visualisation, Writing - original draft, Writing - review \& editing Amy Gough: Conceptualization, Formal analysis, Writing - original draft, Writing - review \& editing Paola Vannucchi: Conceptualization, Investigation, Writing - review \& editing Nils K. Lünsdorf: Methodology, Resources, Formal analysis Joseph McNeil: Formal analysis, Investigation, Writing - review \& editing.

\section{Declaration of competing interest}

The authors declare that they have no known competing financial interests or personal relationships that could have appeared to influence the work reported in this paper.

\section{Acknowledgements}

This research utilised samples provided by the International Ocean Discovery Program (IODP) who we thank, specifically the scientific party of IODP Expedition 362. Funding for all analyses in this study was provided by the SE Asia Research Group at RHUL via ENI who we also thank. Andy Carter is thanked for his help with zircon analyses carried out at the London Geochronology Centre and Tobias Salge is thanked for his help with SEM imagery taken at the Natural History Museum. Finally, Massimiliano Zattin is thanked for the handling of this manuscript with Yani Najman and one other anonymous reviewer also thanked for insightful reviews that have greatly improved the text.

\section{Appendix A. Supplementary data}

Supplementary data to this article can be found online at https://doi. org/10.1016/j.marpetgeo.2020.104874.

\section{References}

Allen, R., Carter, A., Najman, Y., Bandopadhyay, P.C., Chapman, H.J., Bickle, M.J., Garzanti, E., Vezzoli, G., Ando, S., Foster, G.L., Gerring, C., 2008a. New constraints on the sedimentation and uplift history of the Andaman-Nicobar accretionary prism, South Andaman Island. Spec. Pap. Geol. Soc. Am. 436, 223.

Allen, R., Najman, Y., Carter, A., Barfod, D., Bickle, M.J., Chapman, H.J., Garzanti, E., Vezzoli, G., Ando, S., Parrish, R.R., 2008b. Provenance of the tertiary sedimentary rocks of the indo-burman ranges, Burma (Myanmar): burman arc or Himalayanderived? J. Geol. Soc. 165 (6), 1045-1057.

Backman, J., Wenhuang, C., Kachovich, S., Mitchison, F., Petronotis, K., Yang, Tao, Zhao, X., 2019. Data report: revised age models for IODP Sites U1480 and U1481, Expedition 362. In: McNeill, L.C., dugan, B., Petronotis, K.E., the (Eds.), Expedition 362 Scientists Proceedings of the International Ocean Discovery Program Volume 362 publications.iodp. Org.

Bandopadhyay, P.C., 2012. Re-interpretation of the age and environment of deposition of paleogene turbidites in the Andaman and Nicobar islands, western Sunda Arc. J. Asian Earth Sci. 45, 126-137.

Black, L.P., Kamo, S.L., Allen, C.M., Davis, D.W., Aleinikoff, J.N., Valley, J.W., Mundil, R., Campbell, I.H., Korsch, R.J., Williams, I.S., Foudoulis, C., 2004. Improved $206 \mathrm{~Pb} / 238 \mathrm{U}$ microprobe geochronology by the monitoring of a traceelement-related matrix effect; SHRIMP, ID-TIMS, ELA-ICP-MS and oxygen isotope documentation for a series of zircon standards. Chem. Geol. 205 (1-2), 115-140.

Blum, M., Rogers, K., Gleason, J., Najman, Y., Cruz, J., Fox, L., 2018. Allogenic and autogenic signals in the stratigraphic record of the deep-sea Bengal Fan. Sci. Rep. 8 (1), 1-13.

Booth, A.L., Chamberlain, C.P., Kidd, W.S., Zeitler, P.K., 2009. Constraints on the metamorphic evolution of the eastern Himalayan syntaxis from geochronologic and petrologic studies of Namche Barwa. Geol. Soc. Am. Bull. 121 (3-4), 385-407.

Bowles, F.A., Ruddiman, W.F., Jahn, W.H., 1978. Acoustic stratigraphy, structure, and depositional history of the Nicobar Fan, eastern Indian Ocean. Mar. Geol. 26 (3-4), 269-288.

Bracciali, L., Najman, Y., Parrish, R.R., Akhter, S.H., Millar, I., 2015. The Brahmaputra tale of tectonics and erosion: early Miocene river capture in the Eastern Himalaya. Earth Planet Sci. Lett. 415, 25-37.

Brookfield, M.E., 1993. The Himalayan passive margin from Precambrian to Cretaceous times. Sediment. Geol. 84 (1-4), 1-35.

Chapman, J.B., Kapp, P., 2017. Tibetan magmatism database. G-cubed 18 (11), 4229-4234. 
Chen, W.H., Yan, Y., Clift, P.D., Carter, A., Huang, C.Y., Pickering, K.T., et al., 2020. Drainage evolution and exhumation history of the eastern Himalaya: insights from the Nicobar fan, northeastern Indian ocean. Earth Planet Sci. Lett. 548, 116472.

Clemens, S.C., Kuhnt, W., LeVay, L.J., Anand, P., Ando, T., Bartol, M., Bolton, C.T., Ding, X., Gariboldi, K., Giosan, L., Hathorne, E.C., Huang, Y., Jaiswal, P., Kim, S., Kirkpatrick, J.B., Littler, K., Marino, G., Martinez, P., Naik, D., Peketi, A., Phillips, S. C., Robinson, M.M., Romero, O.E., Sagar, N., Taladay, K.B., Taylor, S.N., Thirumalai, K., Uramoto, G., Usui, Y., Wang, J., Yamamoto, M., Zhou, L., 2016. Site U1443. Indian monsoon rainfall. Proceedings of the international ocean discovery program 1-41.

Clift, P.D., Hodges, K.V., Heslop, D., Hannigan, R., Van Long, H., Calves, G., 2008. Correlation of Himalayan exhumation rates and Asian monsoon intensity. Nat. Geosci. 1 (12), 875-880.

Clift, P.D., 2017. Regional context of the geology of the Andaman-Nicobar accretionary ridge. Geological Society, London, Memoirs 47 (1), 19-26.

Cobbing, E.J., Pitfield, P.E.J., Darbyshire, D.P.F., Mallick, D.I.J., 1992. The granites of the South-East Asian tin belt. Br. Geol. Surv., Overseas Memoir 10. HMSO 369.

Curray, J.R., 2014. The Bengal depositional system: from rift to orogeny. Mar. Geol. 352, 59-69.

Curray, J.R., Moore, D.G., 1974. Sedimentary and tectonic processes in the Bengal deepsea fan and geosyncline. In: The Geology of Continental Margins. Springer, Berlin, Heidelberg, pp. 617-627.

De Smet, M.E.M., Barber, A.J., 2005. Sumatra: Geology, Resources and Tectonic Evolution, vol. 31. Geological Society, London, Memoirs, pp. 86-97.

Dunkl, I., von Eynatten, H., Andò, S., Lünsdorf, K., Morton, A., Alexander, B., et al., 2020 Comparability of heavy mineral data - the first interlaboratory round robin test. Earth Sci. Rev. 103210.

France-Lanord, C., Spiess, V., Klaus, A., Schwenk, T., the Expedition 354 Scientists, 2016. Bengal fan. In: Proceedings of the International Ocean Discovery Program, vol. 354. International Ocean Discovery Program, College Station, Texas. https://doi.org/ 10.14379/iodp.proc.354.2016.

Gaetani, M., Garzanti, E., 1991. Multicyclic history of the northern India continental margin (Northwestern Himalaya) (1). AAPG Bull. 75 (9), 1427-1446.

Galy, V., France-Lanord, C., Peucker-Ehrenbrink, B., Huyghe, P., 2010. Sr-Nd-Os evidence for a stable erosion regime in the Himalaya during the past 12 Myr. Earth Planet Sci. Lett. 290 (3-4), 474-480.

Gardiner, N.J., Searle, M.P., Morley, C.K., Robb, L.J., Whitehouse, M.J., Roberts, N.M., et al., 2018. The crustal architecture of Myanmar imaged through zircon U-Pb, Lu-Hf and O isotopes: tectonic and metallogenic implications. Gondwana Res. 62, 27-60.

Garzanti, E., 1999. Stratigraphy and sedimentary history of the Nepal Tethys Himalaya passive margin. J. Asian Earth Sci. 17 (5-6), 805-827.

Garzanti, E., Limonta, M., Resentini, A., Bandopadhyay, P.C., Najman, Y., Andò, S., Vezzoli, G., 2013. Sediment recycling at convergent plate margins (Indo-Burman ranges and Andaman-Nicobar Ridge). Earth Sci. Rev. 123, 113-132.

Garzanti, E., Vezzoli, G., Andò, S., Limonta, M., Borromeo, L., France-Lanord, C., 2019. Provenance of bengal shelf sediments: 2. Petrology and geochemistry of sand. Minerals 9 (10), 642.

Garzanti, E., Andò, S., Vezzoli, G., 2020. Provenance of cenozoic Indus fan sediments (IODP sites U1456 and U1457). J. Sediment. Res. 90 (9), 1114-1127.

GEBCO, 2003. IHO-UNESCO, General Bathymetric Chart of the Oceans, Digital Edition http://www.gebco.net/.

Gehrels, G.E., DeCelles, P.G., Ojha, T.P., Upreti, B.N., 2006. Geologic and U-Th-Pb geochronologic evidence for early Paleozoic tectonism in the Kathmandu thrust sheet, central Nepal Himalaya. Geol. Soc. Am. Bull. 118 (1-2), 185-198.

Gehrels, G., Kapp, P., DeCelles, P., Pullen, A., Blakey, R., Weislogel, A., Ding, L. Guynn, J., Martin, A., McQuarrie, N., Yin, A., 2011. Detrital zircon geochronology of pre-Tertiary strata in the Tibetan-Himalayan orogen. Tectonics 30 (5).

Gough, A., Hall, R., BouDagher-Fadel, M.K., 2020. Mid-Cenozoic fluvio-deltaic to marine environments of the Salin Sub-basin, Central Myanmar. J. Asian Earth Sci. 190, 104143.

Hall, R., 2012. Late Jurassic-cenozoic reconstructions of the Indonesian region and the Indian ocean. Tectonophysics 570, 1-41.

Hall, R., Sevastjanova, I., 2012. Australian crust in Indonesia. Aust. J. Earth Sci. 59 (6), 827-844.

Harbury, N.A., Kallagher, H.J., 1991. The Sunda outer-arc ridge, north Sumatra, Indonesia. J. Southeast Asian Earth Sci. 6 (3-4), 463-476.

Hu, X., Jansa, L., Chen, L., Griffin, W.L., O’Reilly, S.Y., Wang, J., 2010. Provenance of lower cretaceous Wölong volcaniclastics in the Tibetan tethyan Himalaya: implications for the final breakup of eastern gondwana. Sediment. Geol. 223 (3-4), 193-205.

Huyghe, P., Bernet, M., Galy, A., Naylor, M., Cruz, J., Gyawali, B.R., Gemignani, L., Mugnier, J.L., 2020. Rapid exhumation since at least 13 Ma in the Himalaya recorded by detrital apatite fission-track dating of Bengal fan (IODP Expedition 354) and modern Himalayan river sediments. Earth Planet Sci. Lett. 534, 116078.

Ingersoll, R.V., Suczek, C.A., 1979. Petrology and provenance of Neogene sand from Nicobar and Bengal fans, DSDP sites 211 and 218. J. Sediment. Res. 49 (4), 1217-1228.

Jackson, S.E., Pearson, N.J., Griffin, W.L., Belousova, E.A., 2004. The application of laser ablation-inductively coupled plasma-mass spectrometry to in situ U-Pb zircon geochronology. Chem. Geol. 211 (1-2), 47-69.

Jena, B., Kurian, P.J., Avinash, K., 2016. Morphology of submarine channel-levee systems in the eastern Bay of Bengal near Andaman region. J. Coast Conserv. 20 (3), 211-220.

Krishna, K.S., Ismaiel, M., Srinivas, K., Rao, D.G., Mishra, J., Saha, D., 2016. Sediment pathways and emergence of Himalayan source material in the Bay of Bengal. Curr. Sci. 363-372.
Lafuente, B., Downs, R.T., Yang, H., Stone, N., 2015. The power of databases: the RRUFF project. In: Armbruster, T., Danisi, R.M. (Eds.), Highlights in Mineralogical Crystallography, vol. 1. W. De Gruyter, Berlin, Germany, p. 30.

Licht, A., Dupont-Nivet, G., Win, Z., Swe, H.H., Kaythi, M., Roperch, P., Ugrai, T., Littell, V., Park, D., Westerweel, J., Jones, D., Poblete, F., Aung, D.W., Huang, H., Hoorn, C., Sein, K., 2019. Paleogene evolution of the Burmese forearc basin and implications for the history of India-Asia convergence. Bulletin 131 (5-6), 730-748.

Licht, A., Win, Z., Westerweel, J., Cogné, N., Morley, C.K., Chantraprasert, S., et al., 2020. Magmatic history of central Myanmar and implications for the evolution of the Burma Terrane. Gondwana Res. 87, 303-319.

Limonta, M., Resentini, A., Carter, A., Bandopadhyay, P.C., Garzanti, E., 2017. Provenance of Oligocene Andaman sandstones (Andaman-Nicobar islands): ganga-brahmaputra or irrawaddy derived? Geological Society, London, Memoirs 47 (1), 141-152.

Liu, C.Z., Chung, S.L., Wu, F.Y., Zhang, C., Xu, Y., Wang, J.G., Chen, Y., Guo, S., 2016. Tethyan suturing in Southeast Asia: zircon U-Pb and Hf-O isotopic constraints from Myanmar ophiolites. Geology 44 (4), 311-314.

Lünsdorf, N.K., Kalies, J., Ahlers, P., Dunkl, I., von Eynatten, H., 2019. Semi-automated heavy-mineral analysis by Raman spectroscopy. Minerals 9 (7), 385.

Maurin, T., Rangin, C., 2009. Structure and kinematics of the Indo-Burmese Wedge: recent and fast growth of the outer wedge. Tectonics 28 (2).

McNeill, L.C., Dugan, B., Backman, J., Pickering, K.T., Pouderoux, H.F., Henstock, T.J., Petronotis, K.E., Carter, A., Chemale Jr., F., Milliken, K.L., Kutterolf, S., Mukoyoshi, H., Chen, W., Kachovich, S., Mitchison, F.L., Bourlange, S., Colson, T.A., Frederik, M.C.G., Guerin, G., Hamahashi, M., House, B.M., Hupers, A., Jeppson, T.N., Kenigsberg, A.R., Kuranaga, M., Nair, N., Owari, S., Shan, Y., Song, I., Torres, M.E., Vannucchi, P., Vrolijk, P.J., Yang, T., Zhao, X., Thomas, E., 2017. Understanding himalayan erosion and the significance of the Nicobar fan. Earth Planet Sci. Lett. 475, 134-142.

Mitchell, A.H.G., 1993. Cretaceous-Cenozoic tectonic events in the western Myanmar (Burma)-Assam region. J. Geol. Soc. 150 (6), 1089-1102.

Mitchell, A.H.G., 2010. The Chin Hills segment of the Indo-Burman Ranges: not a simple accretionary wedge. In: Proceedings of the Seminar on Indo-Myanmar Ranges in the Tectonic Framework of the Himalaya and Southeast Asia. Manipur University, Conchipur, 2008, pp. 3-24.

Moore, D.G., Curray, J.R., Emmel, F.J., 1976. Large submarine slide (olistostrome) associated with Sunda Arc subduction zone, northeast Indian Ocean. Mar. Geol. 21 (3), 211-226.

Moore, G.F., Curray, J.R., Emmel, F.J., 1982. Sedimentation in the Sunda trench and forearc region. Geological Society, London, Special Publications 10 (1), 245-258.

Morton, A.C., 1984. Stability of detrital heavy minerals in tertiary sandstones from the north sea basin. Clay Miner. 19 (3), 287-308.

Morton, A.C., Hallsworth, C.R., 1999. Processes controlling the composition of heavy mineral assemblages in sandstones. Sediment. Geol. 124 (1-4), 3-29.

Morton, A.C., Hallsworth, C., 2007. Stability of detrital heavy minerals during burial diagenesis. Dev. Sedimentol. 58, 215-245.

Naing, T.T., Bussien, D.A., Winkler, W.H., Nold, M., Von Quadt, A., 2014. Provenance study on eocene-miocene sandstones of the rakhine coastal belt, indo-burman ranges of Myanmar: geodynamic implications. Geological Society, London, Special Publications 386 (1), 195-216.

Najman, Y., Bickle, M., BouDagher-Fadel, M., Carter, A., Garzanti, E., Paul, M., Wijbrans, J., Willett, E., Oliver, G., Parrish, R., Akhter, S.H., Allen, R., Ando, S. Chisty, S., Reisberg, L., Vezzoli, G., 2008. The paleogene record of himalayan erosion: Bengal Basin, Bangladesh. Earth Planet Sci. Lett. 273 (1-2), 1-14.

Najman, Y., Allen, R., Willett, E.A.F., Carter, A., Barfod, D., Garzanti, E., et al., 2012. The record of himalayan erosion preserved in the sedimentary rocks of the hatia trough of the Bengal Basin and the chittagong hill tracts, Bangladesh. Basin Res. 24 (5), 499-519.

Najman, Y., Bracciali, L., Parrish, R.R., Chisty, E., Copley, A., 2016. Evolving strain partitioning in the eastern Himalaya: the growth of the shillong plateau. Earth Planet Sci. Lett. 433, 1-9.

Najman, Y., Mark, C., Barfod, D.N., Carter, A., Parrish, R., Chew, D., Gemignani, L., 2019. Spatial and temporal trends in exhumation of the Eastern Himalaya and syntaxis as determined from a multitechnique detrital thermochronological study of the Bengal Fan. Bulletin 131 (9-10), 1607-1622.

Najman, Y., Sobel, E.R., Millar, I., Stockli, D.F., Govin, G., Lisker, F., Garzanti, E., Limonta, M., Vezzoli, G., Copley, A., Zhang, P., Szymanski, E., Kahn, A., 2020. The exhumation of the indo-burman ranges, Myanmar. Earth Planet Sci. Lett. 530, 115948.

Pal, T., 2011. Petrology and geochemistry of the Andaman ophiolite: melt-rock interaction in a suprasubduction-zone setting. J. Geol. Soc. 168 (4), 1031-1045.

Paton, C., Woodhead, J.D., Hellstrom, J.C., Hergt, J.M., Greig, A., Maas, R., 2010. Improved laser ablation U-Pb zircon geochronology through robust downhole fractionation correction. G-cubed 11 (3). https://doi.org/10.1029/2009GC002618.

Paton, C., Hellstrom, J., Paul, B., Woodhead, J., Hergt, J., 2011. Iolite: freeware for the visualisation and processing of mass spectrometric data. J. Anal. Atomic Spectrom. 26 (12), 2508. https://doi.org/10.1039/c1ja10172b.

Pedersen, R.B., Searle, M.P., Carter, A., Bandopadhyay, P.C., 2010. U-Pb zircon age of the Andaman ophiolite: implications for the beginning of subduction beneath the Andaman-Sumatra arc. J. Geol. Soc. 167 (6), 1105-1112.

Petrus, J.A., Kamber, B.S., 2012. VizualAge: a Novel approach to laser ablation ICP-MS U-Pb geochronology data reduction. Geostand. Geoanal. Res. 36 (3), 247-270. https://doi.org/10.1111/j.1751-908X.2012.00158.x.

Pickering, K.T., Pouderoux, H., McNeill, L.C., Backman, J., Chemale, F., Kutterolf, S., Milliken, K.L., Mukoyoshi, H., Henstock, T.J., Stevens, D.E., Parnell, C., Dugan, B., 2020a. Sedimentology, stratigraphy and architecture of the Nicobar fan 
(Bengal-Nicobar fan system), Indian ocean: results from International Ocean Discovery program expedition 362. Sedimentology 67 (5), 2248-2281.

Pickering, K.T., Carter, A., Andò, S., Garzanti, E., Limonta, M., Vezzoli, G., Milliken, K.L. 2020b. Deciphering relationships between the Nicobar and bengal submarine fans, Indian ocean. Earth Planet Sci. Lett. 544, 116329.

Racey, A., Ridd, M.F., 2015. Myanmar offshore petroleum overview. Geological Society, London, Memoirs 45 (1), 57-62.

Rangin, C., Maurin, T., Masson, F., 2013. Combined effects of Eurasia/Sunda oblique convergence and East-Tibetan crustal flow on the active tectonics of Burma. J. Asian Earth Sci. 76, 185-194.

Rangin, C., 2017. Active and recent tectonics of the Burma Platelet in Myanmar. Geological Society, London, Memoirs 48 (1), 53-64.

Rangin, C., 2018. The Western Sunda Basins and the India/Asia Collision: an Atlas. Geotecto, Societe Geologique de France, p. 294.

Ray, J.S., Pande, K., Awasthi, N., 2013. A minimum age for the active Barren Island volcano, Andaman Sea. Curr. Sci. 104 (7), 934-939.

Ryan, W.B., Carbotte, S.M., Coplan, J.O., O'Hara, S., Melkonian, A., Arko, R., Weissel, R. A., Ferrini, V., Goodwillie, A., Nitsche, F., Bonczkouwski, J., Zemsky, R., 2009. Global multi-resolution topography synthesis. G-cubed 10 (3). https://doi.org/ 10.1029/2008GC002332.

Schärer, U., Xu, R.H., Allègre, C.J., 1986. U (Th) Pb systematics and ages of Himalayan leucogranites, South Tibet. Earth Planet Sci. Lett. 77 (1), 35-48.

Schwenk, T., Spieß, V., 2009. Architecture and stratigraphy of the Bengal Fan as response to tectonic and climate revealed from high-resolution seismic data. External Controls on Deep-Water Depositional Systems. Special Publication-SEPM (Society of Sedimentary Geologists) 92, 107-131.

Sevastjanova, I., Hall, R., Rittner, M., Paw, S.M.T.L., Naing, T.T., Alderton, D.H., Comfort, G., 2016. Myanmar and Asia united, Australia left behind long ago. Gondwana Res. 32, 24-40.

Shebanova, O.N., Lazor, P., 2003. Raman spectroscopic study of magnetite (FeFe2O4): a new assignment for the vibrational spectrum. J. Solid State Chem. 174 (2), 424-430.

Sláma, J., Košler, J., Condon, D.J., Crowley, J.L., Gerdes, A., Hanchar, J.M.,

Horstwood, M.S.A., Morris, G.A., Nasdala, L., Norberg, N., Schaltegger, U.,
Schoene, B., Tubrett, M.N., Whitehouse, M.J., 2008. Plešovice zircon—a new natural reference material for $\mathrm{U}-\mathrm{Pb}$ and Hf isotopic microanalysis. Chem. Geol. 249 (1-2), $1-35$.

Spencer, C.J., Kirkland, C.L., Taylor, R.J.M., 2016. Strategies towards statistically robust interpretations of in situ U-Pb zircon geochronology. Geoscience Frontiers 7 (4), 581-589. https://doi.org/10.1016/J.GSF.2015.11.006.

Subrahmanyam, C., Gireesh, R., Chand, S., Raju, K.K., Rao, D.G., 2008. Geophysical characteristics of the Ninetyeast Ridge-Andaman island arc/trench convergent zone. Earth Planet Sci. Lett. 266 (1-2), 29-45.

Sun, X., Sun, W.D., Hu, Y.B., Ding, W., Ireland, T., Zhan, M.Z., Liu, J.Q., Ling, M.X., Ding, X., Zhang, Z.F., Fan, W.M., 2018. Major Miocene geological events in southern Tibet and eastern Asia induced by the subduction of the Ninetyeast Ridge. Acta Geochimica 37 (3), 395-401.

Uddin, A., Kumar, P., Sarma, J.N., Akhter, S.H., 2007. Heavy mineral constraints on the provenance of Cenozoic sediments from the foreland basins of Assam and Bangladesh: erosional history of the eastern Himalayas and the Indo-Burman Ranges. Dev. Sedimentol. 58, 823-847.

United Nations, 1979. Geology and Exploration Geochemistry of Part of the Northern and Southern Chin Hills and Arakan Yoma, Western Burma. Technical Report, 4, United Nations Development Programme, DP/UN/BUR-72-002/13. United Nations, New York, p. 59.

Vermeesch, P., 2018. IsoplotR: a free and open toolbox for geochronology. Geoscience Frontiers 9 (5), 1479-1493.

Wang, J.G., Wu, F.Y., Tan, X.C., Liu, C.Z., 2014. Magmatic evolution of the Western Myanmar Arc documented by U-Pb and Hf isotopes in detrital zircon. Tectonophysics 612, 97-105.

Wetherill, G.W., 1956. Discordant uranium-lead ages, I. Transactions. American Geophysical Union 37 (3), 320. https://doi.org/10.1029/TR037i003p00320. White, L.T., Lister, G.S., 2012. The collision of India with Asia. J. Geodyn. 56, 7-17.

Zhang, J.E., Xiao, W., Windley, B.F., Wakabayashi, J., Cai, F., Sein, K., Wu, H., Naing, S., 2018. Multiple alternating forearc-and backarc-ward migration of magmatism in the Indo-Myanmar Orogenic Belt since the Jurassic: documentation of the orogenic architecture of eastern Neotethys in SE Asia. Earth Sci. Rev. 185, 704-731. 